Devonian Carrier Shells (Euomphalidae)

from North America and Germany

GEOLOGICAL SUR VEY PROFESSIONALAAPER 824 



\section{Devonian Carrier Shells (Euomphalidae)}

from North America and Germany

By ROBERT M. LINSLEY and ELLIS L. YOCHELSON

G E O L O G I G A L S U R V E Y P R O F E S I O N A L P A P E R 824

$A$ study of a behavior pattern in which

foreign matter is attached to the shell of

living and Devonian gastropods

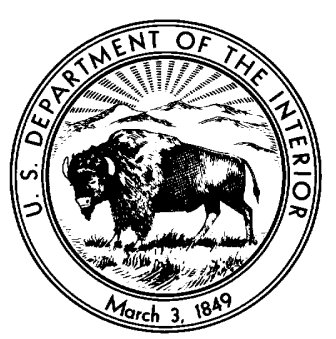

UNITED STATES GOVERNMENT PRINTING OFFICE, WASHINGTON : 1973 
UNITED STATES DEPARTMENT OF THE INTERIOR

ROGERS C. B. MORTON, Secretary

\section{GEOLOGICAL SURVEY}

V. E. McKelvey, Director

Library of Congress catalog-card No. 73-600142

For sale by the Superintendent of Documents, U.S. Government Printing Office, Washington, D.C. 20402 Price $\$ 1.15$ (paper cover) Stock Number 2401-02370 


\section{CONTENTS}

Abstract.

Introduction and acknowledgments.

Implantation among the recent fauna

The Xenophoridae.

Habits of Xenophora conchyliophora

Habits of Xenophora neozelanica

Functional significance of implanted material in the Xenophoridae.

Implantation in fossil gastropod shells.

Systematic paleontology.

Superfamily Euomphalacea

Family Euomphalidae.

Genus Straparollus Montfort

Subgenus Serpulospira Cossman

Subgenus Straparollus Montfort
Page
1

1

2

3

3

4

6

6

7

7

7

7

7

7
8
Systematic paleontology - Continued

Superfamily Euomphalacea - Continued

Family Euomphalidae - Continued Genus Straparollus Montfort - Continued Subgenus Euomphalus J. Sowerby.....

Stratigraphic distribution.

Distribution and nature of implanted material.................. 17

Functional significance of implanted material.................. 18

Presence and absence of implanted materials.................... 19

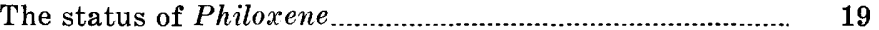

Evolutionary groups of Devonian carrier shells............... 19

Conclusions................................................................. 21

Selected references............................................................ 22

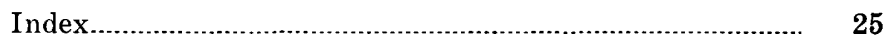

\section{ILLUSTRATIONS}

[Plates follow index]

Plate 1. Xenophora pallidula Reeve.

2. Xenophora neozelanica Suter.

3. Straparollus (Straparollus) and S. (Serpulospira).

4. Straparollus (Straparollus).

5, 6. Straparollus (Euomphalus) and S. (Straparollus).

FIGURE 1. Chart showing stratigraphic occurrence of incrusting euomphalids

2. Drawings showing reconstruction of euomphalids as mobile animals........................... 15

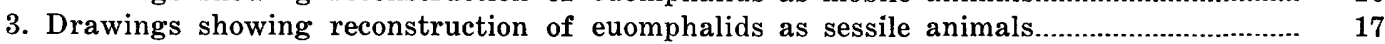


- 


\title{
DEVONIAN GARRIER SHELLS (EUOMPHALIDAE) FROM NORTH AMERICA AND GERMANY
}

\author{
By Robert M. Linsley ${ }^{1}$ and Ellis L. Yochelson
}

\section{ABSTRACT}

The modern carrier shell Xenophora has an elaborate behavior pattern in which the gastropod attaches foreign matter to its shell. The process is a long and deliberate one that has selective significance in terms of visual and olfactory camouflage. Besides the Xenophoridae, first certainly known from the Cretaceous, one turritellid in the Miocene-Pliocene and one Miocene modulid mastered this peculiar art. Various members of the Euomphalacea from the Ordovician, Silurian, and Devonian implanted shell fragments.

The systematic part of this report consists primarily of descriptions of the known Middle and Late Devonian carrier shells of North America; it includes a discussion of eight species, five of which are new. The new species are Straparollus (Straparollus) mortoni, S. (Straparollus) cottrelli, S. (Euomphalus) hoffmani, S. (Euomphalus) winnipegosis, and S. (?Euomphalus) incrustatus. Specimens of the type species of Philoxene and two related forms were also studied.

The Devonian carrier shells are of two or more separate evolutionary stocks having different stratigraphic ranges. One group implants foreign matter regularly; in the other, this feature is quite irregular. Both groups include species having individuals that do not implant material.

In both living and fossil carrier shells, the animals show little preference in materials selected except on the basis of size. The implanted material probably served primarily as tactile camouflage as well as visual camouflage.

Philoxene Kayser is based on implantation and is here regarded as based on a spurious concept. The type species should be placed in the Straparollus senso stricto and other species distributed under various subgenera of Straparollus; implantation alone seems a poor criterion for discriminating a species. The species studied in this paper are treated under three subgenera: Straparollus (Straparollus), S. (Serpulospira), and S. (Euomphalus). Species of $S$. (Euomphalus) in which implantation occurs seem to indicate that the angulated whorl profile characteristic of this taxon evolved more than once in time.

\section{INTRODUCTION AND ACKNOWLEDGMENTS}

Kayser (1889, p. 292) established the genus Philoxene and designated Euomphalus laevis Archiac and Verneuil (1842) as type species. The genus was judged distinct from other euomphalid gastropods because individuals attached foreign matter, usually shell fragments, to their shells. As Knight (1941,

1Department of Geology, Colgate University, Hamilton, N.Y. p. 241) noted in his comprehensive study of Paleozoic gastropod type species, the holotype of $E$. laevis does not have any foreign material attached to its shell. Other specimens, which are presumably conspecific, to some degree do cement shell material to their shells.

Examination of topotypic material of the type species of Philoxene and of all the available Devonian species in North America that attach foreign material suggests that this peculiar habit may be indulged in by individuals within a population but is not necessarily followed by all members. Our study has also demonstrated that the implantation of foreign matter on the shell is not restricted to a particular shell form but cuts across the lines of three currently recognized subgenera. These observations raise questions concerning the taxonomic, functional, and stratigraphic significance of this particular trait as well as the biologic validity of Philoxene. In an attempt to understand the problems presented by these Devonian forms, we have examined the modern carrier shell Xenophora and the closely related $T u$ gurium.

The present study is a fusion of interests originally derived from two separate geographic areas. More than a decade ago, M. H. Staatz, U.S. Geological Survey, submitted for examination a collection from Nevada which was later identified as Philoxene. The effort required to transport a large block of limestone for acid treatment from an area difficult of access is cordially acknowledged.

For the past 10 years, Linsley has been engaged in a study of the gastropod fauna of the Rogers City Limestone. Access to the Calcite quarry, Michigan Limestone Operations, U.S. Steel Corp., at Rogers City, Mich., and to the Presque Isle Corporation quarry (formerly Lake of the Woods quarry) north of Alpena, Mich., managed by Mr. Roy Hutchison for a consortium of steel companies, has always been graciously granted. Field investigations in 1966-69 were supported by the Research Council of Colgate 
University. In addition, during 1965 , the National Science Foundation provided a grant to support a collecting trip by 10 high school students under Linsley's supervision. Further, the Research Council of Colgate University provided an Undergraduate Research Participation Grant which permitted John Cottrell and John Hoffman to assist with fieldwork. Naming of two species after these assistants is a partial acknowledgment of the calibre of help they provided throughout the various stages of this investigation.

Specimens were generously loaned by Dr. Roger Batten, American Museum of Natural History (AMNH). Large collections were lent for study by the Museum of Paleontology, University of Michigan (UMMP). Dr. G. M. Ehlers, University of Michigan (deceased), first introduced Linsley to the Rogers City Limestone and was an indefatigable collector and field companion. An unusual specimen from New York was donated by Dr. H. B. Rollins, University of Pittsburgh. G. Arthur Cooper, U.S. National Museum, has repeatedly given us choice specimens and has been a constant source of stratigraphic information. Access to the collections of the Division of Mollusks, U.S. National Museum, has been unlimited, and the staff, particularly J. P. E. Morrison, have shared their knowledge with us. Drs. C. M. Yonge, University of Edinburgh; E. C. Jones, Bureau of Commercial Fisheries, Honolulu; and E. Alison Kay, University of Hawaii, also discussed living forms in some detail with one or both of us.

In 1971, the Colgate Research Council provided support that enabled Linsley to spend 2 months at the Department of Zoology, University of Auckland, New Zealand, studying living Xenophora under the general direction of Dr. J. E. Morton. Collections of living material were made possible by Dr. Hinde of the Marine Department, Bureau of Fisheries, New Zealand, who placed the research vessel Ikatere (Captain Turner) at Linsley's disposal. Two students from the University of Auckland, Roger Grace and Anthony Ayling, provided Linsley with sorely needed expertise during this cruise. In addition, Grace assisted in setting up the aquariums and provided photographic equipment for this phase of the study. Many members of the faculty of the Zoology Department of the University of Auckland provided hours of stimulating discussion of the problems that arose during this part of the investigation. However, we most particularly thank Dr. Morton for his critical reading of the manuscript and for the many hours he spent sharing with Linsley his thorough knowledge of gastropods in general and of the Xenophoridae in particular.

\section{IMPLANTATION AMONG THE RECENT FAUNA}

The incorporation of foreign bodies into the hard parts of an organism is not a common trait, but it is widespread in a systematic sense. Some Foraminifera have apparently been building an agglutinated test (Towe, 1967) since the Cambrian; other Foraminifera may imbed foreign grains in a calcium carbonate test. A few tunicates and sponges agglutinate sand grains in their flesh, in part, perhaps, accidentally. Worm burrows may be formed of grains of sand bound by mucus, and many worms that live on the bottom construct tubes of clastic grains. Fresh-water caddis fly larvae and terrestrial bagworms are well-known examples of makers of agglutinated tubes. Several animals, such as the "decorator crab," which transfers living sessile organisms to its carapace, are peripheral to those that actually do incorporate material into the shell.

The implantation of foreign material is widespread within the living Mollusca. One living marine pelecypod, Samarangia quadrangularis, Adams and Reeve (see Clench, 1942), attaches sand grains to its smooth shell to such an extent that the nodes and ribs of sand grains cause it to resemble Echinochama. This form is found only off Japan. All other mollusks known to implant foreign material in their shell are Gastropoda. Among this class, Serpulorbis sp., a vermetid from Hawaii (E. Alison Kay, oral commun., 1971), and Scaliola A. Adams (1880), a recent diastomid from the western Pacific, select and implant only sand-sized grains in their shell, whereas Xenophora and Tugurium use a variety of sizes of material. Scaliola is widespread in the Indian and western Pacific Oceans, and it uses whatever grains are present in the environment. Thus, populations from Bikini and from Wednesday Island implant only sand-grain-sized particles of calcite, whereas populations off Japan utilize grains of quartz or black minerals (J. P. E. Morrison, oral commun., 1970, and examinations of mollusk collections of the U.S. National Museum). The Hawaiian species of Serpulorbis implants calcareous sand grains, presumed to be the only grains available in their environment. This discovery of implantation by Serpulorbis is new, and there has not been any detailed investigation as yet.

Members of two genera of land snails also commonly incrust their shells with foreign matter. Thysanophora horni (Gabb) and T. incrustata (Poey) of the Family Sagdidae commonly affix soil and fecal matter to their shells by agglutinating it with mucus which they secrete (Pilsbry, 1940, p. 985; Clench, 1942, p. 74). Gastrocopta pentodon (Say), a member of the Pupillidae and a common dweller in 
leaf mold in the eastern part of the United States, also uses mucus to agglutinate soil and fecal matter to its shell (J. P. E. Morrison, oral commun., 1970). Both Thysanophora and Gastrocopta have white shells, and the attachment of foreign materials does render their shells less conspicuous in the leaf-mold habitat. This action is more related to activities like those of the "decorator crab" than it is to true implantation of material.

Some Cassis have a very thick and featherylike periostracum to which mud adheres, and the mud serves as camouflage (J. P. E. Morrison, oral commun., 1970). There may be other living forms that camouflage the periostracum. Although this serves the same effect in obscuring the general shape as does attaching matter directly to the shell, it is most unlikely that evidence of such a habit would be preserved in the fossil record.

Xenophora and Tugurium are worldwide in distribution in tropical and subtropical waters. Because of their success and because they are so firmly fixed in the popular literature of shell collecting as "carrier shells," it is appropriate that they be considered in more detail.

\section{THE XENOPHORIDAE}

The family Xenophoridae consists of more than two dozen living and extinct species. Wenz (1940, p. 905-909) placed this family in the Strombacea; it includes the extinct genus Endoptygma and questionably the Jurassic genera Jurassiphorus and Lamelliphorus, as well as two living genera. Sohl (1960, p. 96) placed the Late Cretaceous Endoptygma in synonymy of Xenophora. Although Jurassiphorus and Lamelliphorus have the same general conical shape as Xenophora, apparently these fossil forms lack all evidence of implantation, and they may not be related. Cox (in Morton, 1958, footnote on p. 100) independently reached the conclusion that these two genera have questionable relationship to the Xenophoridae. The two modern genera that constitute the Xenophoridae are Xenophora Fischer von Waldheim and Tugurium P. Fischer (in Wiener). Morton (1958, p. 96-100) argued convincingly that the Xenophoridae are more closely related to the Calyptreacea than to the Strombacea.

The species of the genus Xenophora, as determined from examination of shells of the living $X$. conchyliophora Born, $X$. corrugata (Reeve), X. pallidula (Reeve) (pl. 1, figs. 1-5) - perhaps the most striking of the modern carrier shells $-X$. caperata Philippi, $X$. konoi Habe, and $X$. neozelanica Suter (pl. 2, figs. 1-5), and others are all characterized by an abundance of incrusted foreign matter.
Tugurium is divided into three subgenera: Tugurium (Tugurium), T. (Trochotugurium) Sacco, and T. (Haliphoebus) P. Fischer (in Wiener). In contrast to Xenophora, the genus Tugurium has little, if any, implanted matter. Shells of modern species that were examined include especially $T$. (T.) exutum (Reeve), T. (Trochotugurium) borsoni (Bellardi), T. (Trochotugurium) longleyi (Bartsch), $T$. (Trochotugurium) caribeum (Petit), and T. (Haliphoebus) solaris (Linneaus). These forms have evolved a frill that extends from the periphery down over the base much like a skirt.

T. (Haliphoebus) solaris is a most handsome shell whose frill has been modified to consist of long, slender spinelike extensions from the periphery. In its youthful stages, this species implants foreign material not unlike a typical Xenophora. When spines begin to form by the third or fourth volution, the organism loses the implanting habit.

In T. (Trochotugurium) indicum (Gmelin), $T$. (Trochotugurium) helvacea (Phillippi), and $T$. (Trochotugurium) borsoni (Bellardi), implantation only occurs in the youthful stages. Again, after three or four whorls, the skirtlike frill forms, and no further implantation takes place. In T. (Trochotugurium) longleyi (Bartsch) and T. (Trochotugurium) calculiferum (Reeve), a frill forms, and the implanting habit continues throughout the life of the individual. The size and amount of implanted material is very small, however, as compared with that used by Xenophora, so that the shell is neither supported nor hidden by the incrusted material. In all the Xenophoridae that we have examined, save one, foreign matter is implanted at the lower edge of the outer whorl face. In T. (Trochotugurium) lamberti souverbie, however, material is implanted at the suture (the upper edge of the outer lip) rather than at the periphery (lower edge of the outer lip). The habit persists throughout the life of the individual, but again the implanted material neither supports nor hides the shell.

In T. (Tugurium) exutum (Reeve), mature individuals rarely show any implantation, and only a few individuals in the collections of the U.S. National Museum show some implantation in the very early whorls. The margin of the frill is sinuous so that it appears to have broad, blunt "spines" or flanges.

HABITS OF XENOPHORA CONCHYLIOPHORA

Most of the Xenophoridae live below wave base and are commonly reported in depths of 100 to 1,000 feet. As a result, much of our information about them is based on shells dredged from the ocean floor, 
and opportunity for first-hand observation has been limited.

However, Xenophora conchyliophora occurs at quite shallow depths in Florida. Mr. Paul Shank managed to keep specimens alive in aquariums for 2 years. According to Shank (1969), X. conchyliophora spends most of its life withdrawn within its aperture and feeds on microscopic algae by extending its proboscis to the substrate. Thus it does not place its entire foot on the substrate in order to feed. "When food is plentiful it never reaches beyond the limits of its shell, but feeds entirely on the material beneath its shell" (Shank, 1969, p. 5).

Further (Shank, 1969, p. 6), X. conchyliophora buries its feces by forcing the substrate apart with its propodium and probocis, placing the feces in the hole, and using its proboscis to rake the hole shut.

Mr. Shank is one of the few people who have been able to observe the process of cementation at first hand. His account of the process is herein quoted in its entirety (Shank, 1969, p. 6) :

The placing of the rubble isn't merely a matter of positioning shell against it and cementing it fast but a meticulous job on the part of the mollusk. The rubble is turned over, twisted around, or upended to get it into the exact position whereas [sic] it has a downward slope in relation to the shell. It is also brought into contact with the mantle and usually in such a position that the weight of the shell is partially holding it in position. The Xenophora uses its head and proboscis placed below rubble to raise it into place and its foot to raise and lower its shell at the same time, jockeying the two into position. Rubble is not turned by clasping between the propodium and metapodium as I have read but rather it is clasped between the base of the antennae and the proboscis. Flat pieces are actually picked up in this manner while the mollusk is standing on its foot holding its own shell up so rubble can be worked to a more suitable position beneath the previously attached rubble. Up to an hour and a half is sometimes spent getting the rubble into position. Sand is raked from under the rubble with the proboscis to assure more slope and consequently leave more space beneath the shell after attachment is completed.

After rubble is finally jockeyed into a suitable position the job is still not finished. The Xenophora then carefully cleans all the area coming in contact with the mantle to insure a tight joint during the process of cementing it fast. Gaps are checked between the mantle and rubble and filled in by sticking pieces of sand and tiny pieces of debris to the mantle edge by cleaning them and placing them there with the proboscis, one piece at a time. Occasionally, it sticks its head and proboscis under rubble for support and very gently rocks shell to and fro, evidently checking rubble for security of attachment. With the larger pieces of rubble the mollusk remains stationary for over ten hours to assure a tight bond before resuming its food hunting.

HABITS OF XENOPHORA NEOZELANICA

In 1971 , the senior author had the privilege of spending 2 months with Dr. John Morton, Department of Zoology, University of Auckland, New Zea- land. Specimens of Xenophora neozelanica Suter, were dredged off New Zealand. These were kept alive for study in aquariums at the Zoology Department for more than 4 months.

Young Xenophora neozelanica Suter have a predominantly white body; orange pigmentation forms primarily in the region of the proboscis and tentacles. In the adult organism, the entire upper surface of the foot is bright orange, and this color extends well up the muscular column inside the shell. This column is essentially circular in cross section and remarkably protrusible (pl. 2, figs. 2, 4).

The proboscis is well developed in Xenophora, very extensible and quite muscular (pl. 2, figs. 1, 3, 5). It is flanked by two long tentacles, and the eyes are on slight swellings at the base of the tentacles. These tentacles are moderately muscular and were observed to hold lightweight objects being scraped by the radula. However, they were never observed lifting shell material for implantation as has been described for Xenophora conchyliophora (Shank, 1969, p. 6).

The foot is keyhole shaped, having a constriction between propodium and metapodium (pl. 2, fig. 5). The propodium is very broadly expanded laterally. The flat plantar surface of the metapodium is continuous with that of the propodium and is narrower than the propodium but has not been reduced to a narrow median keel (Morton, 1958, p. 91). The operculum is on the posteriormost part of the foot, and the metapodium expands at the back to accommodate this broad structure (pl. 2, fig. 5).

The operculum is conchyolin and noncalcified. It is subtriangular, the base of the triangle extending out over the rear of the metapodium to engage the substrate. The operculum has almost no curvature. Its central area has a narrowly triangular muscle scar extending from the apex almost to the base.

According to Morton (1958, p. 93), "the food of the Xenophora neozelanica Suter is very bulky and consists of the surface layer of grey muddy silt $* * *$ with organic constituents living and dead." Perhaps as a result of having to process such large quantities of material through its gut, $X$. neozelanica shows greater activity than that described for $X$. conchyliophora. Its foot was frequently in contact with the substrate. Thus, this species of Xenophora is as close to being an unselective deposit feeder as any mollusk, and its feces are therefore of large bulk. $X$. neozelanica was not observed to bury its feces as has been reported for $X$. conchyliophora. However, observation of this habit is uncertain, for it is very difficult to observe activities going on under the "tent flaps" of implanted material.

Movement by Xenophora is generally described as 
a "leaping" motion (Morton, 1958, p. 91), but it more closely resembles a one-legged stomp. The plantar surface of the foot is placed against the substrate, and the shell is lifted by extension of the muscular column. Next the shell is thrust forward for about half its diameter, and it then falls forward. When the foot is being lowered to the substrate from its retracted position, the operculum is pointed straight down as though it would dig into the substrate. However, in observing the movement of $X$. neozelanica against a wide variety of substrates, the operculum was always found to be flat against the substrate, in the same plane as the plantar surface of the foot.

The motion in Xenophora is sudden and discontinuous. This is consistent with the motion of other like-camouflaged organisms, for slow, continuous motion would draw attention to them. It also results in a discontinuous track which would tend to thwart predatory organisms using olfactory senses to "sniff out a trail." Normal locomotion of the strombids is to crawl along the substrate, but they are also capable of an escape motion by digging the operculum into the substrate and then flinging the body forward. Xenophora neozelanica did not show such a reaction, nor has it been seen to crawl.

Specimens placed in the presence of starfish (Coscinasterias) and a variety of oyster drills showed no change in their motion. The general reaction of Xenophora to these predators was one of apparent unconcern. They did not even withdraw into their shells but continued to feed and move even though the drills or starfish were directly atop them.

The force provided by the extension of the muscular column is surprisingly great. Many Xenophora shells were incrusted by masses of organisms whose entire weight exceeded that of the shell itself, yet they were able to lift it without any difficulty. Individuals moved even though two or even three other Xenophora were piled on top of them.

The incrusting organisms could be located asymmetrically to one side of the shell, creating considerable imbalance, but the carrier shell had no difficulty in compensating for this. The muscular column is capable of remarkable extension, equal to at least the height of the shell. This extension is utilized when the edge of the shell becomes propped up on some object, when a tipped-over shell is righted, when foreign matter is affixed to the shell, and, presumably, during copulation, although the last has never been witnessed. This extension is apparently accomplished by contraction of the circular muscles around the body stalk forcing blood into the pedal haemocoel.

The method of manipulation and implantation of foreign material proved to be completely different in Xenophora neozelanica than in X. conchyliophora. The tentacles of $X$. neozelanica do not appear sufficiently muscular to handle the large shells normally implanted by adult shells. Young specimens might use this method, although it seems more likely that individuals would consistently use the same technique throughout their growth. In adults, when the time comes to attach new shell material, the animal turns upside down beneath its tentlike shell so that the plantar surface of the foot is directed upward and the proboscis is placed against the substrate (pl. 2, fig. 4). The organism can still maneuver with full effectiveness by pushing down against the substrate with its proboscis. It can easily make adjustments in positioning the shell while in this attitude and occasionally even take "steps." This position now places the foot in an ideal position to search the environment for a shell suitable for implantation.

During the search, the animal is capable of extending its body far out from under its shell (pl. 2, fig. 2). The foot searches among various available shells for an appropriate one to be placed in position for cementation. From the search behavior, the criterion for selection is thought to be primarily one of size. The materials available in the aquarium consisted of either limestone pebbles or bivalve shells, and both were selected by different individuals. The one distinction that was obviously made was between bivalve shells that were concave side down in the substrate and those that were convex side down. Those that were concave side down were flush against the bottom and proved very difficult for the carrier shell to pick up with its foot. Those that were convex side down were easy to pick up. When an object was picked up, the plantar surface of the foot crawled under, using the wavelike muscular contraction typical of most gastropodal locomotion. These contractions of the foot were only seen in Xenophora when shells were picked up for implantation and when an inverted shell was righted, whereupon the foot was used to "crawl" into the substrate for purchase.

Once the carrier shell grasped the foreign object for implantation, it maneuvered its own shell into position for the process by pushing down against the substrate with its proboscis, while the propodium brought the foreign shell into appropriate position. A pelecypod valve would be leaned against the carrier shell concave side outward. The mantle then cemented the valve into place. Unfortunately it was impossible to observe the conclusion of this process in Xenophora neozelanica, but it is presumed to be similar to the concluding phases of cementation in Xenophora conchyliophora. 


\section{FUNCTIONAL SIGNIFICANCE OF IMPLANTED MATERIAL IN THE XENOPHORIDAE}

There can be little doubt that the implanted material on shells of the Xenophoridae serves as camouflage. The behavior of the organism is consistent with this function. Discontinuous and occasional movement, intermittent placement of the foot on the substrate, and burial of the feces are all traits consistent with animals that depend upon hiding. This gastropod has probably evolved both visual and olfactory camouflage by these behavioral features.

The implanted material seems to have a second function which might be even more significant than camouflaging. In the genus Xenophora, the implanted foreign material is positioned so that the pieces act as stilts which lift the entire base and the aperture up off the substrate. In the closely related genus Tugurium, this stiltlike function of the implanted material is supplanted by the presence of a frill (in T. (Tugurium) and T. (Trochotugurium)) or long spines (in T. (Haliphoebus)). In Tugurium, the implanted material is present only in immature specimens where it would seem to be functional prior to the formation of the frill. In the adult stage, the implanted material is either completely absent or is reduced in amount so that it is nonfunctional in raising the shell above the substrate. We would suggest that once the implanted material was acquired, further selection for it in terms of camouflage effect would take place. The eventual stiltlike function which originally provided at least some olfactory camouflage became equal in importance through continued evolution of the group. The genus Tugurium would then be a deep-water adaptation where olfactory camouflage was more important than visual camouflage. As a result, the tentlike frill and spines were sufficient to replace the implanted material as a means of lifting the soft parts of the gastropod off the substrate. The geologic record of the group supports the notion of a later appearance for the more advanced Tugurium.

\section{IMPLANTATION IN FOSSIL GASTROPOD SHELLS}

In reviewing the literature concerning Devonian Philoxene, references were found to other gastropods that have a Xenophora-like habit, and it seems appropriate to mention these additional forms. Species of Xenophora are known from Late Cretaceous to Holocene; Cossmann $(1915$, p. 187) stated that the typical subgenus of Tugurium is not known as a fossil, though subsequently it has been found in Miocene rocks of the Pacific region (MacNeil, 1960, p. 47). The few Cretaceous and Tertiary fossil forms of this family that we have examined show the characters of this group in a consistent manner.
Psammodulus Collins (1934), a member of the modulids, occurs in the middle Miocene of Tehuantepec, Mexico. This form is comparable to the living Scaliola in that the small animal uses only grains of sand size. It shows a fair degree of selectivity by using only quartz. The average size of grains increases as shell size increases. In general, the grains are attached in rows crudely paralleling the aperture.

Springvaleia Rutsch (1943) is a most unusual turritellid from the Miocene of Trinidad and Pliocene of Venezuela (Woodring, 1958; Weisbord 1962, p. 150-152). It appears to be unique among the turritellids in being the only member of a very large and successful family to effect a Xenophora-like facade of implanted shell material. The camouflage appears to be quite good in that an estimated 70-80 percent of the original shell is hidden by the incrusting material. Most of this material consists of fragments of mollusks, bryozoans, barnacles, and even flat rocks.

Devonian species that might be ascribed to Philoxene are discussed in some detail in the section "Systematic Paleontology." In reviewing the genus, Cossmann (1915, p. 148-149) listed the type and only one other species, the Middle Devonian Euomphalus serpens Phillips, as redescribed under Philoxene by Whidborne (1891, p. 241, pl. 24, figs. 1-5). This species, as illustrated, does show small, closely spaced impressions so high on the whorl that they are just below the upper whorl surface. They are quite atypical of the scars on all other forms that we have studied directly. Whidborne does illustrate specimens of Philoxene laevis that show more characteristic cicatrices. He also described and illustrated the species Philoxene philosophus, which has prominent cicatrices; for some reason, this species was overlooked by Cossmann. Because we have no specimens of these two species in hand, we have excluded them from the systematic section and in fact have limited our studies primarily to North American forms.

The only other Paleozoic gastropod known to implant foreign material into its shell is Lytospira. Although this open-coiled euomphalid was first named from the Middle Ordovician of Scandinavia in 1896 (Koken, 1896, p. 398), its author did not make mention of an imbedding habit. Koken (Koken and Perner, 1925, p. 112) eventually did note "mehrere Arten bekleben sich mit fremden Schalenstuckchen etc. nach Art der Phoriden." In the interim, species were described from the Silurian of Bohemia, at least one of which, Lytospira subuloidea Perner (1907, p. 143, text fig. 180), shows irregularities, presumably from shell matter embedded 
near the periphery. No illustrations of other species described from the Ordovician and Silurian of both areas show any cicatrices.

Yochelson (1963, p. 179) restudied Lytospira norvegica Koken and confirmed that this species does bear scars from attachment of foreign matter (Yochelson, 1963, pl. 5, fig. 7). However, at the time he did not study the possible individual variation in implantation within the available specimens of one species. In retrospect, the only additional comment is that scars, if they were present on many of the specimens, were few and were widely spaced; the point should be investigated. Yochelson (1963, p. 179) also erred in that, although he thought that the widely disjunct (open-coiled) form indicated a sedentary life habit, he ascribed an active mode of life to Xenophora because of its efforts in collecting shells and, by inference, transferred this same presumed activity to $L$. norvegica.

In the Middle Ordovician of the United States, Ulrich and Scofield (1897, p. 1036-1037) redescribed Eccyliomphalus undulatus Hall, a widely open-coiled species. They noted that "depressions on the outer side of the shell are due to agglutinated foreign objects like fragments of Orthis." Another widely disjunct Middle Ordovician species, Cyrtolites trentonensis Conrad, transferred to Eccyliomphalus by Weller $(1903$, p. 184), is represented in the collections of the National Museum by four specimens. On the best preserved of these, several attachment scars are evident. The types of both species have not been investigated. The relationship between Lytospira and Eccyliomphalus remains to be clarified, but presence or absence of incrusting material would be an unsatisfactory character to use in distinguishing these genera. Widely disjunct gastropods should be examined to see if other species have the habit of implantation.

\section{SYSTEMATIC PALEONTOLOGY}

\section{Superfamily EUOMPHALACEA Family EUOMPHALIDAE \\ Genus Straparollus Montfort \\ Subgenus Serpulospira Cossmann}

Straparollus (?Serpulospira) eboracensis (Hall)

Plate 3, figures 19-21

Euomphalus eboracensis Hall 1861, p. 27; Hall 1862, p. 55, Hall 1876, pl. 16, figs. 19-23.

Euomphalus (Phanerotinus) eboracensis Hall 1879, p. 61, pl. 16, figs. 19-23.

Description. - Moderately large discoidal gastropods with rapidly expanding whorls and disjunct coiling of the adult whorl. Early whorls poorly known. Aperture poorly known, apparently subcircular to elliptical in cross section; growth lines indi- cate a simple prosocline aperture. Sutures very deep in early whorls, later whorls slightly disjunct; upper and outer whorl face rounded and continuous below periphery; lower part of outer whorl face flattened locally by adpressed foreign material; slight angulation at base of attachment zone separating outer and basal whorl faces; base unknown; umbilicus unknown, presumably widely phaneromphalus. Growth lines faint. Foreign matter attached at or below periphery with irregular spacing. Shell structure unknown, apparently moderately thick.

Discussion. - Hall (1861, p. 27) described some rather poorly preserved shells "In the shales of the Hamilton Group at Eighteen-mile Creek in Erie County and at York, in Livingston "Co., N.Y." as Euomphalus eboracensis. The specimen illustrated herein was loaned by Dr. Roger Batten, American Museum of Natural History (AMNH). It has a width of $30.9 \mathrm{~mm}$ and height of approximately $11 \mathrm{~mm}$.

This is a most perplexing specimen. Hall's original designation of this specimen as Phanerotinus has nothing to support it, for there is no trace of the leaflike expansions that are diagnostic of that genus. However, our placement of this species in the subgenus $S$. (Serpulospira) is also questionable. As far as we can judge, the whorls are disjunctly coiled, but the whorl diameter increases more rapidly than is typical in S. (Serpulospira). The specimen is also different from other species described herein in that it has used primarily brachiopod fragments as the implanted material, though this is an indication of a different habitat rather than a different habit.

The collections of the American Museum of Natural History contain two specimens of this species both under number $\frac{4890}{1}$. Whitfield and Hoovey $(1900$, p. 312$)$ designate this number as "type." The specimen figured here is that illustrated by Hall (1876, pl. 16, figs. 19 and 23 ; refigured in Hall, 1879, pl. 16, figs. 19 and 20). The specimen is designated here as lectotype so as to avoid any further confusion; it is apparent that Hall's drawings have been somewhat idealized.

The lectotype is from "York." The other specimen, from "Eighteen-mile Creek" in Erie County, is an indeterminate steinkern which may be a euomphalacean. In the 1876 and 1879 works, no mention is made of an occurrence other than at York. Collections have not been made at the "York" locality, which is most probably in the Middle Devonian Ludlowville Formation, (G. A. Cooper, oral commun., 1972).

Numbered specimen. - Lectotype: $\mathrm{AMNH} \frac{4890}{1}$. 
Straparollus (Serpulospira) centrifuga (F. A. Roemer) Plate 3, figures 8-11

Discussion. - One specimen (USNM 183651) collected from the Paffrath beds near Bergische Gladbach near Cologne, Germany, by R. M. Linsley and Ulrich Jux, is a typical example of Straparollus (Serpulospira). However, it is unusual in that it shows shallow implantation scars at the whorl periphery. A second specimen (USNM 63406), which was purchased many years ago from a professional collector, is from the Paffrath "near Cologne" Germany and could be from the same locality. This specimen, labeled S. (Serpulospira) serpula Koninck, also shows similar cicatrices, but it is fragmentary and not worth illustrating. Other specimens of this species that we have studied show no evidence of implantation.

These two specimens resemble $S$. (Straparollus) laevis and S. (Straparollus) ?laevis, also from the Paffrath beds, in general whorl cross section. In all, the implantation scars show a marked regularity in both size and spacing, especially when contrasted with the irregularity of the cicatrices of some North American Devonian carrier shells. The attachment scars are at or slightly above the shell periphery.

The species Straparollus (Serpulospira) centrifuga (Roemer) was originally described under Serpularia and considered to be a worm tube. Subsequently, additional specimens were described as Euomphalus serpula by de Koninck (1843, p. 425426). De Koninck included both Middle Devonian and Lower Carboniferous open-coiled forms within the same species. Later authors have transferred specimens of both ages to other genera, including such widely different taxa as Solarium, Straparollus, and Pleurotomaria. Constructing a meaningful synonymy for this taxon is almost a hopeless task; many of the earlier illustrations have been repeatedly reproduced in textbooks with few additional new data.

It is pertinent to note that illustrations of this species given under its various names by various workers show no attachment scars. These illustrations include those of de Koninck (1843, pl. 23 bis., figs. $8 \mathrm{a}, 8 \mathrm{~b}$; pl. 25 , figs. 5a, 5b) ; Goldfuss (1844, pl. 191, figs. 1a-1e); and Sandberger and Sandberger (1850, pl. 25, fig. 9). As noted, the attachment scars we have observed in this species are obscure; that they are not shown in drawings does not necessarily mean that they were consistently absent. Even if all previously described and illustrated specimens lack foreign particles, or at least their attachment scars, the biological situation would be no different from that in S. (Straparollus) cyclostomus (Hall) (p. 10). In both instances, most members of the presumed populations lack any indication of attachment, but a few individuals do maintain this habit.

Numbered specimen. - Hypotype: USNM 183651.

Subgenus Straparollus Montfort

Straparollus (Straparollus) laevis (Archiac and Verneuil) Plate 3, figures 1-3

Discussion. - Three specimens of this species numbered 58498 and 183680 (two specimens in one lot) and 63256 - are in the collections of the U.S. National Museum; both lots were obtained years ago from the Paffrath near Cologne. All these specimens differ from the holotype described by Knight (1941, p. 241) in having abundant scars of attachment. In the figured specimen, the nuclear and juvenile whorls are free of any signs of incrusted material. However, the final three whorls show scars indicating the implantation of foreign matter. The implantation scars are peripheral on the body whorl but are slightly above the periphery on the penultimate whorl. The implantation of material higher on the penultimate whorl would seem to be an adaptation which allows the body whorl to become emplaced in a subplanispiral position, the suture immediately at the base of the implantation scars. This also suggests that the specimen is probably mature, for another whorl could not maintain the nearly planispiral form without interference from the implanted material.

Knight (1941, p. 242) indicated the presence of a parietal inductura. His illustration of the type specimen shows that the body whorl has been broken back for some distance; the impression of the parietal lip on the base of the penultimate whorl may have misled him into interpreting this as an inductura. Although the type specimen does have an upper angulation across which the growth lines are sinuate, both the angulation and the sinus are exceedingly obscure features. The differences between the holotype and the specimens we have examined are so slight that they fall well within the range of variation to be expected in any population of Straparollus. What is significant is the absence of scars of attachment on the type and their obvious presence on conspecific material.

Because this is a common and well-known European species, which has been cited repeatedly, we have not made any attempt to construct a formal synonymy.

Numbered specimens.-Hypotypes: USNM 58498 (figured), 63256, and 183680 . 
Straparollus (Straparollus) ?laevis (Archiac and Verneuil) Plate 3, figures 4, 5

Discussion. - One specimen in the collection of the U.S. National Museum (63255) is labeled $S$. (Philoxene) multispina (Sandberger). This specimen is also from the Paffrath beds near Cologne and bears implantation scars similar to those described above on S. (Straparollus) laevis (Archiac and Verneuil). This specimen differs primarily from those of that species in being so high spired that it is considered trochiform. However, in view of the extremes in shape found in other species which implant, such as $S$. (Euomphalus) hoffmani n. sp., it is conceivable that this specimen may be part of a population of $S$. (Straparollus) laevis. In addition, study of a species of Straparollus from the Early Devonian of Michigan (Linsley, 1968, p. 373-376) suggests that height of spire may be an exceedingly variable character.

The implantation scars are positioned below the periphery and rather low on the outer whorl face. The implanted foreign matter is placed at a position relative to the suture so that each successive whorl impinges below the attached foreign matter on the preceding whorl. Thus on both the body and the penultimate whorls impressions can be seen on the upper whorl face where shell growth had accommodated the implanted foreign matter of the preceding whorl. As the shell completes the next volution, subsequent growth will provide a second attachment site, one on each of two successive whorls.

Another feature of this specimen is the notable regularity of the implantation scars. In general, the size of the scars and thus the inferred size of the implanted fragments increases in proportion to increase in whorl size. The distance between the centers of these scars also increases with marked regularity. Finally, this specimen shows implantation of shell material at an earlier growth stage than do the planispirally coiled individuals of $S$. (Straparollus) laevis. In the specimen, the final three whorls all show attachment scars.

Numbered specimen. - Hypotype: USNM 63255.

Straparollus (Straparollus) sp.

Plate 5, figure 20

Discussion. - A single external mold of a fragment showing two whorls was collected by Dr. Harold B. Rollins, University of Pittsburgh, from the "Cardiff Shale Member" of the Marcellus Shale, Hamilton Group, 3 miles south of Peterboro, N.Y. The preserved part is low trochiform and has a wellrounded whorl profile. The specimen is small and may be immature. It is too incomplete to name for- mally, but the depth of the sutures, which accentuate the roundness of the whorl section, mark it as distinct.

A bryozoan fragment is attached at the periphery of the upper whorl, and this fragment is also incorporated into the lower preserved whorl. There are at least two other fragments closely spaced on the upper whorl in the same position, and several may be seen at the periphery of the lower whorl.

Numbered specimen. - Hypotype: USNM 183652.

\section{Straparollus (Straparollus) mortoni Linsley and Yochelson n. sp. \\ Plate 6, figures 1-4}

Description. - Medium-sized extremely low spired gastropods with rounded elliptical whorl profile, deep sutures, and a wide umbilicus. Nuclear whorls poorly known, apparently simple and dextral. Whorl profile of early growth stages virtually circular. Sutures distinct and deep. Whorl profile becoming increasingly elliptical in maturity with long axis of ellipse nearly at right angles to axis of coiling. Shell height from essentially planispiral to low spired, the body whorl attaching below the periphery in adult forms. Umbilicus poorly known, but wide. Growth lines gently prosocline on upper whorl face, swinging to orthocline on outer whorl face and back to gently prosocline on base. Attachment scars on or below periphery of whorl, relatively large and evenly spaced.

Shell unknown.

Discussion. - This species is known from two external molds. On each of these molds is a badly preserved mold at the site of an attachment scar, which suggests that the attached fragment was also molluscan. The shape of these molds is not good enough for positive identification but suggests fragments of gastropod shells.

This species most closely resembles Straparollus (Straparollus) laevis from Germany in that it is low spired and has evenly spaced attachment scars, whereas all other North American species show great variance and general irregularity in this feature.

$S$. (S.) mortoni also resembles the German carrier shells in the positioning of the implanted material as well as in the spacing. The two specimens of this species that are available for study suggest that the early whorls are planispiral, but that subsequently the whorls are depressed down from the original plane of coiling as the size increases, giving a lowspired adult form. The positioning of the implanted material varies in relation to the position of each successive whorl. In the early planispiral stages, the implanted material is placed at the whorl periphery, 
but in the mature depressed whorls, implantation takes place lower on the outer whorl face. It differs from $S$. ( $S$.) laevis in having larger attachment scars and in having a slightly more rapidly expanding shell, as a result of the elliptical mature whorl profile. Both $S$. (S.) cottrelli and $S$. (S.) cyclostomus are higher spired and have a rounded whorl profile.

Numbered specimens. - Holotype: 183653; figured paratype: 183654.

Straparollus (Straparollus) cyclostomus (Hall)

Plate 3, figures 6, 7, 12-18

Euomphalus cyclostomus Hall, 1858, p. 516, pl. 6, figs. 6a, b, c. Straparollus cyclostomus portlandensis Fenton and Fenton, 1924, p. 177-178, pl. 40, figs. 14, 15.

Description. - Moderately large gastropods varying from low spired to trochiform. Nucleus poorly known, but seemingly simple, dextral and discoidal; nuclear whorls continuous with first two neanic whorls, so that their upper surfaces lie in a horizontal plane. Whorl profile subcircular with only a suggestion of a slight angulation at the juncture of the upper and outer whorl faces; sutures distinct and moderately deep; outer whorl face well rounded; basal surface rounded in early growth stages but flattened slightly at maturity, though without any suggestion of a basal angulation. Widely phaneromphalous; umbilical walls well arched and with distinct basal sutures. Shell planispiral in earlier stages, but gradually becoming increasingly trochiform, with each succeeding whorl in contact at a lower point on the preceding whorl, though with a high degree of individual variation in this feature of ontogenetic change. Shell thick.

Upper part of outer lip essentially orthocline with suggestion of a slight sinus midway between suture and periphery, varying widely below periphery from nearly orthocline to steeply prosocline and orthocline on the base, inductural deposits wanting. Growth lines closely spaced and rugose, with sporadic cementation of shell debris; cementation scars, when present, tend to interfere with growth lines, causing them to be mildly prosocyrt on the outer whorl face. Shell moderately thick, with only slight thinning at parietal lip. Shell structure unknown.

Discussion. - Twenty specimens of this species have been examined. Sixteen individuals formerly on display in an old museum exhibit are catalogued under USNM 9166, 183656, and 183657 "from five miles above Muscatine, Iowa." The collection was not labeled originally as to formation, though Cedar Valley is indicated on a later label. Four other individuals collected by G. A. Cooper are catalogued 183655,183658 , and 183681 from a "quarry on Sweetland Creek, SE1/4, NW1/4, SW1/4, section 27,
T. 7 N., R. 1 W., Muscatine County, Iowa"; this lot is from the upper part of the Coralville Member of the Cedar Valley Limestone. Specimens in both lots are similar, and for convenience we have treated them as one population sample.

Dr. William Furnish, Department of Geology, University of Iowa, noted (written commun., Oct. 17, 1969) :

Cooper's description does not agree precisely with our own (based on Illinois City Quad, 1953, 1:24,000). There are several ledges of Cedar Valley exposed in the east half of the NW $1 / 4$, SW $1 / 4$, Sec. 27, T. 77 N., R. 1 W. The older collection is likely from exactly the same place, or almost certainly within a radius of a mile, east or west. The Cedar Valley exposures are rather limited "near Muscatine"; this spot is actually about four or five miles upstream. There has been some uncertainty about stratigraphic position, inasmuch as Stainbrook regarded the Coralville as being absent at Linwood and Buffalo nearby. Faunally, this ledge is certainly Coralville "or younger" according to Gilbert Klapper's analysis of the conodonts. There are no comparable faunas recovered from the type Coralville where the facies is adverse for conodonts.

None of the available specimens of this species show attached foreign material in place (pl. 3, figs. $6,16-18)$. Only four individuals out of 20 have scars or depressions on their shell which indicate that objects were affixed at one time but subsequently have been broken off. On three of the specimens, only a single cementation scar is present (pl. 3, fig. 7). On the fourth (pl. 3, figs. 12-15), there are at least seven and perhaps as many as nine attachment scars on the body and penultimate whorls. This specimen, with a height of $15.2 \mathrm{~mm}$ and a width of $25.0 \mathrm{~mm}$, is only slightly larger than that illustrated on plate 3 , figure 6 . It is somewhat different from the others in having a rugose appearance of the body whorl caused by rather coarsely developed growth lines. Had it not been from the same area and similar in height of spire to the specimen illustrated on plate 3 , figure 6 , it might well have been assigned to a separate species.

In all, this small population is a most diverse group, showing a rather large variation of from $2 / 3$ to $1 / 2$ in height/width ratio. In more mature stages, variation may be seen both in the coarseness of growth lines and in implantation of debris. On all observable specimens, the two nuclear whorls and the first three juvenile whorls are quite smooth. During later growth, there is a tendency for the whorl to become more or less rugose in appearance because of irregularities of the growth lines. When implantation of foreign material does occur, it is only on the rugose area of the shell. The foreign matter is implanted at or very slightly above the periphery of the whorl. On the specimen with multiple cicatrices, 
the body sworl is positioned so that the suture occurs just at the base of the implantation zone.

Although there may be a difference in size between the Cedar Valley specimens described above and the "Hackberry" forms described by Fenton and Fenton (1924), size alone is a highly subjective character and one that may be suspect, for it depends to a large degree on the amount of collecting and the abundance of the species. We prefer not to give any weight to it. As Fenton and Fenton discussed no other characters, and as their illustrations are similar to those of Hall, we have placed their variety in synonymy of this species. However, we have not examined Hall's type material nor that of the "variety" portlandicus (Fenton and Fenton, 1924, p. 177) from the "Hackberry," and our opinion is subject to subsequent confirmation.

So far as we can determine, $S$. (S.) cyclostomus has not been formally described or illustrated by other workers. It has been listed as either Straparollus or Euomphalus and as occurring in the Cedar Valley Limestone of Illinois (Savage, 1920, p. 180), in the Ouray Limestone of Utah (Hintze, 1913, p. 111), and in the Martin Limestone of Arizona (Ransome, 1916, p. 142), but none of these occurrences have been documented, and we have not made any attempt to confirm them.

S. (Straparollus) cyclostomus is readily distinguished from S. (Straparollus) laevis and S. (Straparollus) incrustatus by its low spire. It is quite similar in general shape to $S$. $(S$.) cottrelli, but the absence of a circumbilical ridge distinguishes it.

Numbered specimens. - Hypotypes: USNM 9166 (unfigured), 183655 (figured), 183656 (figured), 183657 (figured), 183658 (figured), and 183681 (unfigured).

\section{Straparollus (Straparollus) cottrelli Linsley and Yochelson n. sp. Plate 4, figures 1-12}

Description. - Low-spired broadly phaneromphalous gastropods with rounded whorls. Nuclear whorls unknown. Sutures moderately deep. Whorl profile smooth, curved from suture to base following the outline of a wide downwardly inclined oval; some individuals with profile showing slight flattening so as to accentuate upper and outer whorl faces. Umbilicus wide and deep; umbilical sutures sharp and deeply incised; mature stage most commonly has low circumbilical ridge on basal whorl face. Apertural margin complete, circular in profile, lips showing no thickening; outer lip orthocline, with no reentrants or salients interrupting it; basal lip sharply prosocline. Parietal inductura absent. Shell ornamented by fine, closely spaced growth lines. Foreign shell material, when present, cemented to periphery of several mature whorls. Shell thickness unknown.

Discussion. - This species is known from a collection of about 70 specimens from the basal 6 feet of the Rogers City Limestone (unit 1 of Ehlers and Radabaugh, 1938). The sediment was apparently deposited as a supratidal dolomite, for the rock is a cryptocrystalline laminated dolomite with scattered mud-crack layers and scattered layers of shell hash (pl. 4, fig. 14). These shelly layers are interpreted as the result of storms which threw the shells into the supratidal zone where the dolomites were forming. As such, the specimens found in this unit are in a transported fossil assemblage (Fagerstrom, 1964), and from their present associations, little can be inferred of their ecology.

In general, this species resembles $S$. (Euomphalus) hoffmani n. sp., also from the Rogers City Limestone, in having a circumbilical ridge. S. (Straparollus) cottrelli differs from that species primarily by having an obviously rounded whorl profile and in being lower spired. S. (Straparollus) cottrelli can be readily differentiated from $S$. (Straparollus) ?laevis by its smaller umbilicus, the presence of a circumbilical ridge, and a less rounded whorl profile. $S$. (Straparollus) cottrelli is like $S$. (Straparollus) cyclostomus in having a low spire height and a rounded whorl profile, but the circumbilical ridge in this form readily distinguishes the two species. $S$. (Straparollus) cottrelli has a more rounded whorl profile and is much lower spired than S. (?Euomphalus) incrustatus.

Like other species of Devonian carrier shells, $S$. (Straparollus) cottrelli shows considerable variation. The circumbilical ridge is only slightly developed in some individuals (pl. 4, fig. 4) and rarely is as prominent as in $S$. (Euomphalus) hoffmani. A few specimens (pl. 4, fig. 6) have little if any foreign matter implanted in the shell, whereas others (pl. 4, figs. 1-3, 7) have an abundance of attached materials. Most specimens have a rounded whorl profile (pl. 4, figs. 11, 12) characteristic of the typical subgenus. Several (pl. 4, figs. 2, 10) have developed a faint angulation between the upper and outer whorl faces, thereby assuming an appearance similar to that of the subgenus Euomphalus; this flattening of the profile is not a result of postmortem crushing of the shell.

One interesting aspect of this species is that many individuals have been preserved with the attached foreign matter intact, so that one can actually see what was cemented without having to try to infer it from the attachment scars. For the most part, the attached material consists of entire gastropod shells 
of several sorts, but there is an occasional tentaculitid or broken shell fragment of undetermined origin. Judging from the molds and steinkerns, this species had a shell of moderate thickness.

Units 2 and 3 of the Rogers City Limestone overlying the beds that contain $S$. (Straparollus) cottrelli are 7 feet thick, but in contrast to unit 1, they mainly lack gastropods; unit 2 is essentially unfossiliferous, and unit 3 carries only Atrypa in profusion. Only two euomphalids have been obtained from units 2 and 3 . They are both incomplete but seem to be intermediate in height of spire between S. (Straparollus) cottrelli and S. (Euomphalus) hoffmani. The specimen from unit 2 (USNM 183662, pl. 4, fig. 11) is sufficiently similar to $S$. (Straparollus) cottrelli to warrant its inclusion in this species. However, the specimen from unit 3 (USNM 183664, pl. 4, fig. 13) lacks the circumbilical ridge and has a relatively narrow umbilicus which suggests that it is higher spired. It seems to lack an upper angulation, but it does have abundant attachment scars. Thus, the specimen has features that are essentially intermediate between $S$. (Straparollus) cottrelli and $S$. (Euomphalus) hoffmani as well as an intermediate stratigraphic position. Because of the apparent intermediacy of features combined with the paucity of material, we have only provisionally assigned this specimen to $S$. (Straparollus) cottrelli.

Numbered specimens.-Holotype: USNM 183659; figured paratypes: USNM 183660, 183661, 183662, 183663, and 183679 and UMMP 22375.

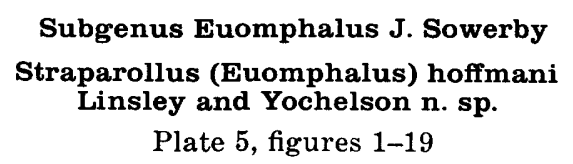

Description. - Relatively high spired, phaneromphalous, moderately large euomphalaceans. Nucleus and early growth stages unknown. Suture distinct, of variable depth. Pleural angle $50^{\circ}$ to $80^{\circ}$. Juvenile whorls moderately rounded. Whorl profile in mature stage roughly pentagonal; upper whorl face flattened to gently arched, inclined $45^{\circ}$ below horizontal, with a prominent shoulder at juncture of upper and outer whorl face; nearly vertical outer whorl face flat to gently arched, and joining base at an equally prominent angulation; base flattened, inclined gently downward from outer angulation to prominent cordlike circumbilical ridge; at circumbilical ridge, whorl profile turning steeply upward into moderately narrow umbilicus; umbilical suture poorly known. Growth lines opisthocyrt on upper whorl face, bending to orthocline on outer whorl face and continuing orthocline over basal part of whorl and into the umbilicus. Parietal inductura absent, revolving ornament consisting only of circumbilical cord and angulations bounding outer whorl face; transverse ornament of fine closely spaced growth lines. Shell moderately thick; its structure unknown.

Discussion. - This species is by far the largest of all the Devonian carrier shells. Its strong circumbilical cord, angulated profile, and high spire make it distinctive. It is also the most consistent implanter of foreign matter among all the Devonian species considered in this paper. All 52 specimens collected show attachment scars, whereas in most of the other "populations," attachment is rare. S. (Euomphalus) hoffmani is also noted for implanting far more foreign matter per individual than the other species. The foreign matter has been separated from the molds of all specimens of this species, and knowledge of its nature is by inference from examination of the cicatrices. The attachment scars of typical mature specimens are exceptionally large and crowded; although occasionally an entire volution may exist with no attachments having been made (pl. 5, fig. 9), this is rare.

There appears to be a fairly consistent relationship between spire height and the time of first implantation of shell particles. In general, the higher spired shells (those with a smaller pleural angle) implanted foreign matter earlier in life than the lowspired shells. For example, the high-spired shell shown on plate 5 , figures 15,18 , and 19 , has implantation scars at the beginning of the third volution, whereas the low-spired specimen shown in figures 4,8 , and 12 has no scars until the beginning of the fourth volution.

Counting whorls in individuals of this species is most difficult, for in every specimen the nuclear whorls have been broken off, frequently in the same relative position, adding to the disreputable overall appearance of the shell. Septation or apical plugging appears to have been relatively common in these shells, for frequently the steinkern terminates abruptly apicad with a rounded, smooth surface.

This species is known from 52 specimens from the upper 58 feet of the Rogers City Limestone (units 4-6 of Ehlers and Radabaugh, 1938). Most of the specimens were collected from the shore of Lake Huron 0.6 mile north of Rockport quarry, Alpena County, Mich. Others were obtained from rubble on the Lake Huron beach of False Presque Isle, just north of Knight's Bay, or from rubble of the Calcite quarry at Rogers City, Mich.

Numbered specimens. - Holotype: UMMP 22369; figured paratypes: UMMP 22370, 22372, 22374, 
57888, and 57889 and USNM 102938, 183665, 183666, and 183667.

\section{Straparollus (Euomphalus) winnipegosis Linsley and Yochelson n. sp. Plate 6, figures 19, 21}

Description.-Trochiform gastropods with a moderately high spire and a deep umbilicus. Nuclear whorls unknown. Pleural angle about $90^{\circ}$. Suture moderately deep. Whorl profile of immature whorl circular in cross section, gradually developing an upper shoulder which becomes pronounced in more mature whorls; upper whorl face flattened and depressed about $30^{\circ}$ below horizontal, but in more mature stage concave with flat band near shoulder; outer whorl face rounded in neanic whorls, flattened in mature whorls; whorl face curving smoothly onto base without angulation. Base poorly known, apparently without circumbilical ridge. Umbilicus poorly known, possibly deep. Growth lines with shallow sinus on both upper and outer whorl faces; outer lip gently opisthocyrt on upper whorl face, rather sharply prosocyrt over shoulder and once again gently opisthocyrt on outer whorl face and continuing in orthocline manner onto base. Ornament consisting only of fine growth lines. Shell unknown, apparently of moderate thickness. Entire outer whorl face serving as area for implantation of foreign matter.

Discussion. - This species is known from the external mold of a single specimen collected from the Winnipegosis Formation. S. (Euomphalus) winnipegosis resembles $S$. (Euomphalus) hoffmani n. sp. from the Rogers City Limestone in overall shape and also shows abundant attachment scars on the outer whorl face. It has a slightly lower spire than that species, shows no evidence of a prominent lower angulation, and has a concave upper whorl face. Although individually these differences are slight, collectively they provide a firm basis for the establishment of a new species.

The gastropod fauna of the Winnipegosis Formation is fairly well known through the work of Whiteaves $(1891 \mathrm{a}, \mathrm{b} ; 1892)$ and more recently McCammon (1960). Even if one ignores the presence of attachment scars, the profile of this species is distinct from other euomphalids described from the region.

The locality is in a quarry in Lsd. 4, Sec. 21, Twp. 24 , Range $10 \mathrm{~W}$ PM, about one-fourth mile west of the Narrows, Lake Manitoba. It is stop 18 of the guidebook prepared by McCabe (1967), and it is approximately a mile west of locality 1 of McCammon $(1960$, p. 10).

Numbered specimen. - Holotype: USNM 183668.
Straparollus (?Euomphalus) incrustatus Linsley and Yochelson n. sp.

Plate 6, figures 5-18, 20

Description. - Trochiform gastropods with a rounded to subelliptical whorl profile and a deep umbilicus. Nucleus unknown. Whorl profile varying from subcircular in juvenile stage, through subangular to slightly pendant at maturity; suture deep; upper whorl face moderately well arched between suture and outer whorl face; slope of arched outer whorl face declining with age and having periphery low on whorl ; slight basal angulation; base flattened for most of its width but proceeding into umbilicus with strong curvature. Umbilicus moderately wide and deep; umbilical sutures very deep. Parietal inductura absent. Ornamentation consisting of closely spaced faint growth lines, orthocline on upper whorl surface, shallowly opisthocyrt along outer whorl face and orthocline on base. Attached foreign material or scars of attachment variably positioned on outer whorl face and closely but irregularly spaced and seemingly absent on early whorls. Shell moderately thick; its structure unknown.

Discussion. - This species is known from about 19 silicified specimens collected by M. H. Staatz in 1954 from the Middle Devonian of Utah (USGS loc. 5829-SD). Much of the material is fragmentary, and several specimens are crushed. In general, the gradual change from the moderately higher spired early stage to the broader mature body whorl is comparable to that of the genus Omphalotrochus; the shape is best described as crudely pagodiform. This ontogenetic change in the shape of the whorl profile is regular, but because most specimens do not preserve the various growth stages, the first impression is of great diversity and irregularity. The holotype, slightly crushed, measures $17.0 \mathrm{~mm}$ in width and $12.5 \mathrm{~mm}$ in height.

All specimens save one are closely comparable to the holotype. This single juvenile (paratype 183677 , pl. 6, figs. 5-7), differs from the rest of the sample in having a pendant whorl profile with the outer whorl face quite flattened and inclined at about a $45^{\circ}$ angle to the axis of coiling. Other specimens of about the same size have already formed a whorl wider than high.

This species is also unusual in that all specimens have many attachment scars. Some still show foreign shell matter attached to the shell. The one identifiable piece of attached foreign matter is a complete immature specimen of $S$. (?Euomphalus) incrustatus. Two other attached pieces may be fragments of gastropod shells, though the identification is in doubt because of their incompleteness. The shell in 
areas of attachment is exceedingly thin, and perhaps was so thin that it could not silicify. As a consequence, the shells are fragile and therefore especially susceptible to crushing.

S. (?Euomphalus) incrustatus is higher spired than S. (Straparollus) cottrelli and S. (Straparollus) cyclostomus, and it has less rounded whorls than either of these. The flattened outer whorl face distinguishes it from $S$. (Straparollus) laevis. $S$. (?Euomphalus) incrustatus resembles $S$. (Euomphalus) hoffmani in spire height; the latter species does not undergo the ontogenetic change of spire height and consistently has an angulation between the upper and outer whorl faces. The lack of a circumbilical ridge at all growth stages readily distinguishes $S$. (?E.) incrustatus from $S$. (E.) hoffmani. The oval to pendant whorl profile and the absence of a concave upper whorl face distinguish this species from $S$. (E.) winnipegosis.

Numbered specimens.-Holotype: USNM 183669; figured paratypes: USNM 183670-183677; unfigured paratypes: USNM 183678 (10 specimens).

\section{STRATIGRAPHIC DISTRIBUTION}

German species discussed in this paper are from beds best characterized by the Givetian brachiopod Stringocephalus. The association of Devonian carrier shells with Stringocephalus or with other elements of the stringocephalid fauna is maintained in several of the occurrences in North America. This suggests that it is worth exploring whether the incrusting habit might be of some stratigraphic significance. The occurrence of species discussed in this paper is shown in figure 1.

The one undisputed association of a carrier shell with Stringocephalus in North America is that of Straparollus (Euomphalus) winnipegosis, n. sp., from the Winnipegosis Formation of Manitoba, where it occurs with Stringocephalus cf. S. sapiens Crickmay.

Farther southwest, S. (?Euomphalus) incrustatus, n. sp., was collected from low in the upper part of the Engelmann Formation of Utah; it was originally listed as Straparollus cf. S. ophirensis Hall and Whitfield, a Mississippian form. It occurs with Athyris cf. A. angelicoides Merriam (Staatz and Carr, 1964, p. 52). Fossils in the Engelmann are sparce and rarely well preserved, but lower in the formation, poorly preserved brachiopods were identified by C. W. Merriam as "probably Stringocephalus sp." (Staatz and Carr, 1964, p. 52). A post-Givetian age is indicated for the part of the Engelmann that yielded this species of Straparollus. Poole and others $(1967$, p. 887$)$ give a general correlation of this formation.
Although Stringocephalus has not been identified in the Rogers City Limestone of northeastern Michigan, other elements of the North America Givetian Stringocephalus fauna do occur. Straparollus (Euomphalus) hoffmani, n. sp., occurs in the upper part of the Rogers City Limestone with a diverse fauna including such stratigraphically significant forms as Atrypa arctica, Subrensselandia sp., Liromytilus attenuatus, Omphalocirrus sp., and Buechelia tyrrellii. Straparollus (Straparollus) cottrelli, n. sp., occurs in the lower part of the Rogers City, where the fauna is more restricted but does include Carinatina dysmorphostrota, generally considered a member of the Givetian equivalent fauna (Ehlers and Kessling, 1970, p. 29).

The remaining species cannot be readily correlated with the Stringocephalus fauna. Presumably this fauna was an incursion from the north, and in the Eastern United States the incursion was of brief duration. This is best seen in the Michigan section, where the Traverse Group is readily correlated with the New York section. In Michigan, S. (Straparollus) mortoni from the "Gravel Point Formation" is clearly younger than the Stringocephalus fauna of the Rogers City; it is impossible to determine whether this species is younger than or equivalent to the Stringocephalus fauna which occurs in Manitoba.

In New York, the Marcellus Shale is considered to be Eifelian (Cooper and Phelan, 1966, p. 8). Straparollus (Straparollus) sp. occurs in the "Cardiff Shale Member," the uppermost member of the formation. Although we have followed Cooper and Phelan in indicating a break between the Marcellus and the overlying Skaneateles, this may not be of any great time significance; this species might be in beds equivalent to the Rogers City. The Ludlowville species S. (?Serpulospira) eboracensis, in spite of the uncertainty that surrounds its precise occurrence, is definitely from beds younger than those on this continent considered to contain Stringocephalus.

Most species noted occur within the Cazenovian and Tioughniogan Stages of American usage. However, S. (Straparollus) cyclostomus (Hall) from the "Coralville Member" of the Cedar Valley Limestone in Iowa definitely occurs in younger beds, considered to be Taghanican in age (Cooper and others, 1942; Cooper and Phelan, 1966, p. 9). Thus, in North America, Devonian euomphalids that have the incrusting habit are widely distributed stratigraphically within the Middle Devonian. The Iowa occurrence may be in beds of earliest Late Devonian age (Johnson, 1970, p. 2080). The western species $S$. (?Euomphalus) incrustatus is from beds of Frasnian Age.

It is difficult to make an exact correlation of the 


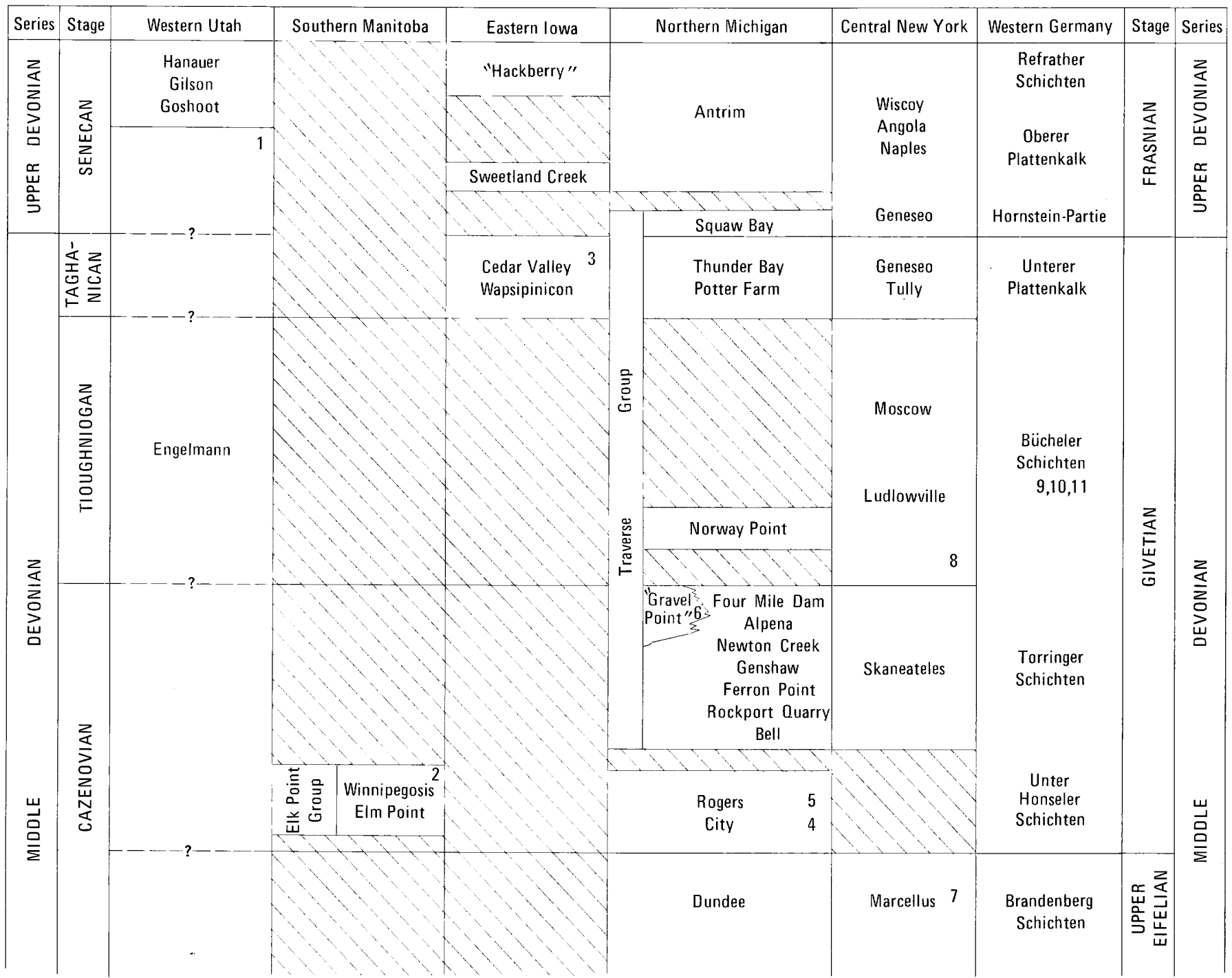

FigURE 1. - Stratigraphic occurrence of incrusting euomphalids, mainly from Cooper and Phelan (1966). Utah column from Poole and others (1967) ; column for German material from Jux (1964, and written commun., 1972) and Erben and Zagora (1967). Intercontinental correlations from Johnson (1970). Occurrence of species indicated by numbers: 1, Straparollus (?Euomphalus) incrustatus, n. sp.; 2, S. (Euomphalus) winnipegosis, n. sp.; 3, S. (Strapa-

German beds that have produced incrusting specimens. The similarity between the Rogers City fauna and that of the Bücheler beds is impressive, but the best available correlations suggest that Stringocephalus in the German section might be younger than in Michigan.

We conclude that identification of the incrusting habit in a Euomphalus could be supporting evidence for assigning a Middle to early Late Devonian age to a fauna. In the absence of any other faunal elements, however, assumption of a Middle Devonian age would be hazardous. Even though we know of no Paleozoic occurrences other than those described herein and scattered Ordovician and Silurian forms rollus) cyclostomus (Hall); 4, S. (Straparollus) cottrelli, n. sp.; 5, S. (Euomphalus) hoffmani, n. sp.; 6, S. (Straparollus) mortoni, n. sp.; $7, S$. (Straparollus) sp.; 8, S. (?Serpulospira) eboracensis (Hall); 9, S. (Straparollus) laevis (Archiac and Verneuil); 10, S. (Straparollus) ?laevis (Archiac and Verneuil); 11, S. (Serpulospira) centrifuga (F. A. Roemer).

which have not been carefully studied, this may be simply a function of incomplete collection or poor observation. The incrusting habit clearly has evolved independently several times and cannot be an infallible stratigraphic indicator.

\section{POSITIONING OF SHELL DURING IMPLANTATION}

In the modern xenophorids, the positioning of incrusted materials is consistent, with the exception of Tugurium (Tugurium) lambertï. The latter is said by Tryon (1886, p. 162) to implant foreign matter at the suture, whereas all other xenophorids implant their foreign matter at the periphery. 
In the Devonian carrier shells from Germany there is some variation in the point of implantation of foreign material. This variation seems to correlate well with height of spire. In $S$. (Straparollus) ?laevis, a low-spired almost discoidal form (p. 9), the implantation scars are at the periphery of the shell. In S. (Straparollus) laevis, a higher spired form, the cicatrices are distinctly below the periphery. In each, the incrusted material does not interfere with the growth and positioning of the succeeding whorl. This next whorl abuts just below the implanted material of the preceding whorl; the implanted material will sometimes be cemented to both whorls.

In Straparollus (Serpulospira) centrifuga, the disjunct nature of the whorls obviates the considerations on placement mentioned above. Yet the positioning of the incrusting material on the periphery is the same pattern as in S. (Straparollus) ?laevis, a form which has a comparable low spire height.

The open coiling of this Serpulospira demonstrates that the positioning of incrusted matter in this group of German snails is not dictated completely by the geometry of shell coiling. It is more likely that the positioning of the incrusted matter is determined by the relationship of the shell to the soft parts when implantation takes place. This might be determined either by the amount of regulatory detorsion of the shell, or by its attitude when resting on the substrate.

In a gastropod with a low-spired shell like $S$. (Straparollus) ?laevis, the shell would be balanced on the foot with almost a full $180^{\circ}$ torsion (Naef, 1911) (fig. 2A). In the normal carrying position of this shell, its periphery is directly over the center of the head. However in a gastropod with a higher spired shell like $S$. (S.) laevis, both regulatory detorsion and inclination must occur for the shell to be balanced over the visceral hump of the organism (fig. 2B). This brings the periphery around in the direction of the spire (the animal's right), and a point below the shell periphery will be over the center of the head. This is the normal carrying position for most modern gastropod shells, and if the process of implantation of foreign objects is related to the normal carrying position, then this could explain why higher spired shells may have debris implanted lower on the outer lip than low-spired shells.

Though the explanation presented above fulfills the mechanical requirements to explain variation in position of implantation scars on the German shells, we believe it to be inadequate. The cementation process in Xenophora conchyliophora takes 10 to 12

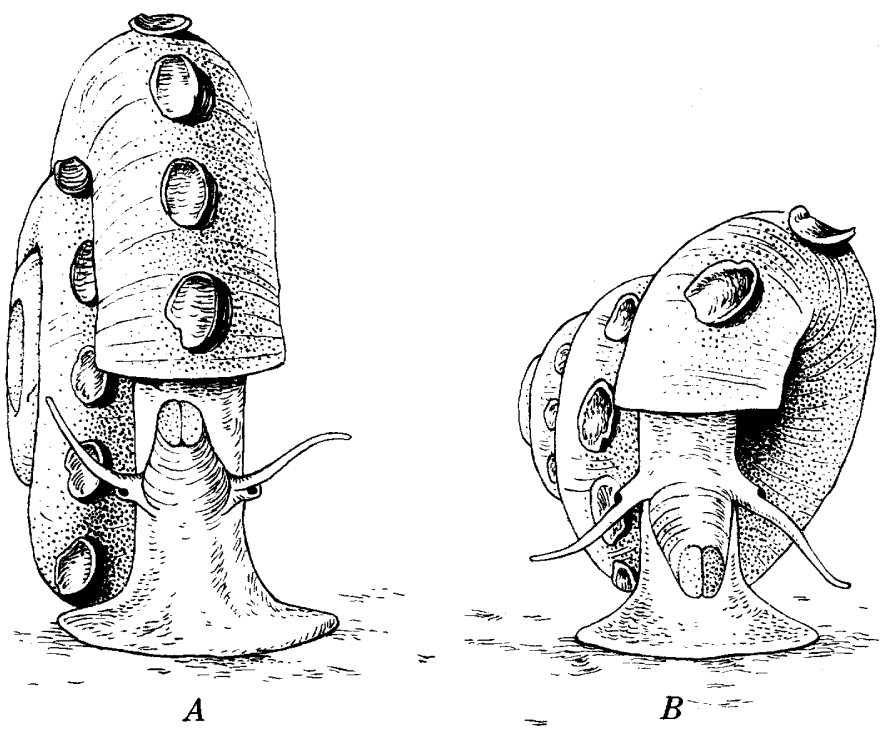

Figure 2. - Reconstruction of euomphalids as mobile animals. $A$, Low-spired form represented by Straparollus (Straparollus) ?laevis, showing torsion with shell essentially symmetrical on the foot. $B$, Higher spired form represented by $S$. (Straparollus) laevis, showing regulatory detorsion and inclination of shell relative to foot.

hours (Shank, 1969, p. 6). Although the fragments cemented by $S$. (Straparollus) laevis were smaller than those used by modern carrier shells, it is doubtful that a sheet of calcium carbonate of sufficient strength to bind the foreign particle could be secreted in any appreciably shorter time. It seems most unlikely that $S$. (Straparollus) laevis could have held its shell motionless in the normal carrying position for the several hours required for this process. Our interpretation is that foreign matter was implanted when the shell rested on the bottom (fig. 3).

If a euomphalid with an implanting habit was sedentary, and if the length of time involved to imbed foreign matter firmly in the shell was commensurate with that of the modern xenophorids, then during implantation the shell must have been resting, umbilicus down, on the substrate. In low-spired shells such as $S$. (S.) ?laevis, foreign matter placed on the sea floor and leaned against the shell would touch it at the periphery (fig. 3A). In high-spired shells such as $S$. (S.) laevis, the spire would slant to one side, and foreign matter similarly placed would strike the shell below the periphery (fig. 3B).

With the exception of $S$. (Straparollus) mortoni, the Devonian carrier shells of North America, unlike their German counterparts, do not show such striking differences in the region of incrustation. Essentially, they all cement the foreign matter somewhere near, but not necessarily at, the periphery. Straparollus (Euomphalus) hoffmani and $S$. (E.) 

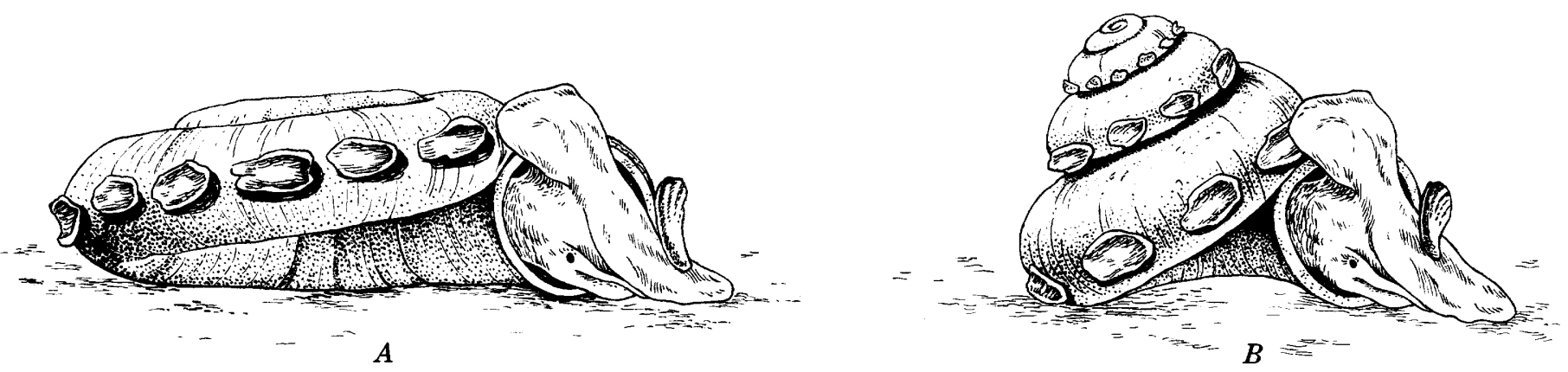

FigURE 3. - Reconstruction of euomphalids as sessile animals. $A$, Low-spired form in process of implanting a fragment at periphery. $B$, Higher spired form engaged in similar activity with the fragment lower on the whorl.

winnipegosis have a flattened outer whorl face, and all implantation takes place within this area. We suggest that this flattened area provided a relatively broad zone, any part of which would have been a stable area against which to lean foreign shell fragments.

S. (?Straparollus) incrustatus is rather high spired, and the implantation scars indicate that foreign matter was attached randomly on the outer whorl surface, some of it high and some of it low.

No operculum is shown in the reconstruction of soft parts in figure 3. In living Xenophora, the operculum is far back on the foot so that part of it is seen extending upward beyond the metapodium. In most living gastropods the operculum is positioned more anteriorward, and one would assume that this position would be similar in earlier forms. In such a location, it would be hidden by the sole in the reconstruction. However, in spite of the lack of any proof of an operculum in the fossil record, we believe that such a structure would likely have been present. For a sedentary form, an operculum would be particularly useful, if only to close the aperture in turbid water. Few opercula are known for the Euomphalacea, but on the basis of scattered observations (Yochelson and Linsley, 1972), we would suspect that a multispiral operculum would be the most reasonable form to fit the aperture. The complex twistings required to affix foreign particles to the shell would make it unlikely that such an operculum would be calcified.

\section{DISTRIBUTION AND NATURE OF IMPLANTED MATERIAL}

As frequently stated in the literature, the modern carrier shell is selective in its choice of implanted material. For example, Sohl $(1960$, p. 96) noted that specimens of Xenophora "from the Ripley formation on Coon Creek, Tennessee, preferred bivalves of the genus Caesticorbula." Observations of museum collections of Xenophora and especially X. pallidula, combined with life studies of $X$. neozelanica, suggest most strongly that although there often is selection of material, it is based only on size of particles available. Except for this criterion, the carrier shells are not selective relative to composition or shape of materials. The size of the foreign material selected increases as the size of the organism increases. Consequently, Xenophora may change from one kind of material or a particular species to another during growth. (See pl. 1.)

In specimens of $S$. (Straparollus) cottrelli, n. sp., S. (Straparollus) sp., and S. (?Euomphalus) incrustatus, $\mathrm{n}$. sp., foreign matter is preserved intact on the shell. S. (Straparollus) cottrelli is the best known species in this regard because of an abundance of specimens with implanted material still intact. The foreign material consists largely of small gastropods, frequently immature members of this species (pl. 4, figs. 2, 3), bellerophontids (pl. 4, fig. 5), and other low-spired gastropods (pl. 4, fig. 1) ; occasionally even high-spired murchisonids are cemented to the shell. Only rarely is material other than gastropods implanted.

The available specimens of Straparollus (?Euomphalus) incrustatus include two examples which have implanted material in place, and again the foreign matter is composed of small gastropod shells. The single specimen of $S$. (Straparollus) sp. has one fragment of a fenestellid bryozoan intact (pl. 5, fig. 20). The single specimen of $S$. (?Serpulospira) eboracensis (Hall) (pl. 3, fig. 20) is scarred with impressions of fragmentary brachiopod valves, mostly of Atrypa sp. (G. A. Cooper, oral commun., 1970).

In the German species, and in S. (Straparollus) mortoni, S. (Straparollus) cyclostomus, and S. (Euomphalus) winnipegosis, there is no way to determine what materials were originally implanted. Cicatrices are distinct, and one would judge that foreign material was firmly implanted. However, Linsley has noted that many individuals of $X$. neozelanica have lost some or even most of their im- 
planted material during life. The loss of foreign fragments cannot be attributed solely to diagenetic effects.

In $S$. (Euomphalus) hoffmani, the cicatrices are distinct, and it is possible in many specimens to determine what had been implanted even though no material is left. It is apparent that crinoid columnals (pl. 5, figs. 15, 18), brachiopods (pl. 5, figs. 5, 6), and gastropods (pl. 5, fig. 17) (either fragmented or entire) were used. We estimate that the material on the shell is in roughly the same proportion as the fragments in the rock matrix.

In the Rogers City collection, calcite fossils such as crinoid stems and brachiopods have been preserved. Gastropod shells and some implanted fragments have been dissolved and thus are known only from external molds or natural casts of secondary calcite. Presumably the euomphalid shell was aragonite which has been differentially dissolved. One result of this is that the natural molds and casts from the Rogers City show selectivity in apparent preservation of implanted material. S. (Straparollus) cottrelli implanted primarily aragonite gastropod shells. In these, both the incrusted shell and its incrustations have dissolved, and the molds show the animal in its full incrusted state. S. (Euomphalus) hoffmani used calcite brachiopods and crinoids for its implanted material. Differential solution left these embedded in the matrix while the aragonite gastropod shell was dissolved from under them. As a result, casts of specimens of $S$. (E.) hoffmani all appear to have had the foreign material broken off ; in fact, most of it is still present in the matrix surrounding the molds. We see no difference in the implantation of calcite or aragonitic material. It is well known that the modern Xenophora is capable of implanting materials that have a wide variety of chemical compositions, including calcite and aragonite shells, phosphate nodules, pebbles of varying mineralogy, and even wood and coal.

One other aspect of implantation is worth noting. The three German species that have been discussed in this paper are similar in that the implantation scars and the implanted material have a marked regularity in size and in spacing. The scars are all small compared with those of American forms and show gradual but regular increase in size, roughly proportional to the increasing size of the whorls. In addition, the separation between the centers of the scars increases, approximately in a logarithmic manner. Those two traits, combined with the uniform positioning of the scars on the whorl, create an overall appearance of marked regularity.

In contrast, the majority of the North American carrier shells are a disreputable-looking lot.
We cannot detect any trends in size or spacing of implantation scars. The one exception among the North American forms is $S$. (Straparollus) mortoni. In this species, the implantation scars increase regularly in size, but they are larger than those of the German forms. The scars are so large that in some areas of the shell they are in contact.

\section{FUNCTIONAL SIGNIFICANCE OF IMPLANTED MATERIAL}

Some earlier literature suggested that the implanted material serves to thicken and strengthen the thin shell of Xenophora. This view of functional morphology is false. The convergence in implantation habit is reinforced by the contrast of the translucent shell of most of the Xenophoridae with the thick shell of the Devonian forms. This thicker shell allowed the implanted material to be placed very deep into the shell without interfering with the internal profile of the whorl as it does in Xenophora. However, the implanted material in these fossils actually resulted in a relative weakening of the shell at the attachment points; the foreign material did not strengthen the shell. The thin shell of modern Xenophora may be viewed as a more efficient means of implanting material. The process of secretion at the mantle edge is faster in the modern forms than in the Devonian species.

In Xenophora, the implanted materials serve at least two functions, that of stilts to support the base of the shell above the substrate and that of camouflage. In the Devonian carrier shells, the implanted materials seem to have functioned solely as camouflage. This role would be perfectly consistent with the assumed ecology of these gastropods, namely as predominantly or entirely sedentary organisms.

The protection provided by the incrusting habit as it was evolved by the various straparollids would seem to be slightly different from that of the modern xenophorids. Even in the most completely covered individuals of $S$. (Euomphalus) hoffmani, only 60-70 percent of the shell is hidden by the incrusting material, whereas in some species of Xenophora the coverage approaches 100 percent. In the less covered euomphalids, the incrustations do little more than slightly interrupt the smooth outline of the shell.

In the Devonian fauna, the most probable predators on the Devonian gastropods were cephalopods, though direct evidence of predation is lacking. It seems doubtful that cephalopods of the Middle Devonian had eyes as well developed as those of the modern coleoids and octopods; they probably had eyes that were no better developed than and probably not as good as those of the living Nautilus. We would suggest that the cephalopods of the Devonian 
could have been more dependent on tactile stimuli for their food search than they were on visual stimuli. If this were true, even a few broken shells attached to the gastropod shell may have had at least limited positive value against the selection pressures exerted by these predators.

\section{PRESENCE AND ABSENCE OF IMPLANTED MATERIALS}

One of the most puzzling aspects of the Devonian carrier shells is the apparent inconsistency in the habit of implanting material. Within some of the assumed life populations, not all members implant foreign material. Of the 11 species of Devonian carrier shells discussed in the systematic section of this paper, seven are known only from single or very few specimens, and we have assemblages of only four of them. From the literature we can infer something about the variation of this feature in two other species.

For the type species of Kayser's genus Philoxene, S. (Straparollus) laevis (Archiac and Verneuil), the Paffrath population includes specimens with and without attachment scars. As noted, the type specimen for $S$. (S.) laevis does not show attachment scars, yet this is the feature on which Kayser based his new genus. Knight stated $(1941$, p. 242$)$ that attachment scars "are present on other probably conspecific specimens." Thus in the Paffrath, there are obviously some specimens of $S$. (S.) laevis (and probably $S$. (S.) ?laevis) that did implant foreign matter and some that did not. The same may be said for S. (Serpulospira) centrifuga (F. A. Roemer). The type specimen shows no sign of attachment scars (Knight, 1941, p. 316), but the specimen figured in this paper leaves no doubt that scars are present on at least one specimen from the Paffrath.

Among the four North American species in which relatively large samples are available for study, we find that in S. (Straparollus) cyclostomus, four of the 20 specimens show cicatrices. In S. (Straparollus) cottrelli, about 40 of the 70 specimens show attachment scars. All 20 specimens of $S$. (Straparollus) incrustatus and all 52 specimens of $S$. (Euomphalus) hoffmani have abundant attachment scars.

The presence or absence of attached material is related to the age of the specimens, for this habit is primarily an adult character. That alone cannot explain all the variations. In all populations studied where implantation may be present, there are large individuals that have no cicatrices. We postulate that, at least intitially, the presence of this habit was dependent upon some triggering mechanism in the environment that was only intermittently present.
According to C. M. Yonge (oral commun., 1970), there is an analog to this environmental factor in the modern shipworm Teredo. If debris of finely comminuted wood is allowed to pile up around the entrance to its burrow, Teredo will secrete a small calcareous tube up through the "sawdust" to keep a clear channel available into its burrow. If, however, wave action is sufficient to sweep away the debris, then no tube is constructed. Thus the presence or absence of this apertural tube is dependent on conditions in the environment. A similar analog is in the pelecypod Amphidesma australe Gray (Roger Grace, oral commun., 1971). The immature members of this species, $3-15 \mathrm{~mm}$ long, that live in a current-swept area of coarse sand secrete a single byssal thread to provide attachment. Similar-sized specimens of the same species that live in quiet water do not secrete a byssal thread.

\section{THE STATUS OF PHILOXENE}

We feel that the presence or absence of attached foreign material in the Devonian carrier shells must be dependent upon an unknown external stimulus, as suggested in the section above. This character is not consistent within a population in some of the species examined. Accordingly, we conclude that the habit of attaching foreign matter to the shell is not an adequate criterion for differentiation of Paleozoic gastropods at any taxonomic level.

Consequently, we here transfer Euomphalus laevis to the typical subgenus of Straparollus so that Philoxene Kayser is placed in synonymy. The various other species that have been assigned to Philoxene should be transferred to the several subgenera of Straparollus, depending on their whorl profile and overall shape. Because the implanting habit is not necessarily constant, some of these species may be placed in the synonymy of nonimplanting species otherwise identical in shape. Currently Philoxene is treated as a subgenus under Straparollus (Knight, Batten, and Yochelson, 1960, p. I-193).

\section{EVOLUTIONARY GROUPS OF DEVONIAN CARRIER SHELLS}

Two distinctive assemblages can be seen within the Devonian species of carrier shells. The first is based on the German forms from the Paffrath beds, and the second is represented by species in the Rogers City and Winnipegosis Formations. Other species may have no relationship to either of these groups.

The three German species S. (Straparollus) laevis, S. (Straparollus) ?laevis, and S. (Serpulospira) centrifuga are all similar in that they have narrow whorls; by this it is meant that the generating curve 
expands very slowly as it is translated along the axis of the cone (Raup, 1966). Further, attachment of foreign matter is an occasional event, most of the individuals of each of the three species not implanting foreign matter. Finally, all the individuals that implant are characterized by having small regularly spaced attachment scars that consistently are on the periphery of the shell. Collectively, these characteristics suggest that the species have a common ancestry.

Straparollus (Straparollus) mortoni from the "Gravel Point Formation" of northern Michigan resembles the German forms in having a low rate of whorl expansion, in having the implanted material positioned consistently at the periphery, and in having a regular spacing of the implanted material. As this species is known from only two specimens, it is not possible to comment on the frequency of the implanting habit. However, there is enough similarity between this species and the German forms to suggest that they are probably related. There is an obvious difference in overall shape between this planispiral form and the low-spired S. (Straparollus) laevis, but the differences are no greater than between $S$. (S.) laevis and the high-spired $S$. (S.) ?laevis or the open-coiled $S$. (Serpulospira) centrif$u g a$. Specimens of some species in the typical subgenus of Straparollus have a great deal of individual variation in general form (Linsley, 1968, p. 373-376).

Straparollus (Straparollus) cyclostomus from the Cedar Valley Limestone of Iowa has a whorl expansion rate similar to that of the first group. It also shows considerable individual variation in height of spire and in presence or absence of cicatrices. It is different in having fewer implantations per individual. On the one specimen which has more than one implantation, the cicatrices are irregular in spacing and position. This species is so far removed temporally from any of the other Devonian carrier shells that any suggestions of relationship are most tentative.

The second and better documented group is exclusively North American and includes S. (Straparollus) cottrelli, S. (Euomphalus) hoffmani, and $S$. (Euomphalus) winnipegosis. The oldest known member of this lineage is $S$. (Straparollus) cottrelli from the basal 6 feet of the Rogers City Limestone of Michigan. This species differs from all those of the first group in having wider whorls; by this it is meant that the generating curve expands more rapidly as it moves along the axis of the cone relative to the first group. It is also distinguishable in having a weak to moderately strong circumbilical ridge. Implantation occurs more frequently within a popu- lation of shells, about 50 percent of the population adopting the habit. The implanted material of this species is not regularly placed on the periphery, and there is considerable variation in spacing and size of the implanted material.

Straparollus (Euomphalus) hoffmani occurs in the upper two-thirds of the Rogers City Limestone. It is separated from $S$. (Straparollus) cottrelli by less than 10 feet of sparsely fossiliferous dolomites and limestones. The only specimens collected from this interval are incomplete, but in some ways they are intermediate between the two (pl. 4, fig. 13). S. (Euomphalus) hoffmani is similar to $S$. (Straparollus) cottrelli in rate of whorl expansion, in the presence of a circumbilical ridge, and in the variation in size and positioning of implanted material. We suggest that it has evolved from $S$. (Straparollus) cottrelli and in the process has acquired a generally larger size, a higher spire, a strong circumbilical ridge, and an angulated whorl profile.

The cross section of each whorl has an angular "euomphalid" shape rather than the rounded "straparollid" whorl profile. In addition, the implantation of foreign matter apparently is ubiquitous in the population, as though the habit or stimulus for implantation was increasing through time.

$S$. (Euomphalus) winnipegosis occurs in the Winnipegosis Formation of Manitoba and is thus difficult to relate temporally to the Michigan species. It resembles the Rogers City forms in having a circumbilical ridge, in a rapid whorl expansion, and in general distribution of incrusted material. As it is currently known from a single specimen, we cannot comment on the frequency of incrusted individuals within a population, but would expect it to be high, because in other features the species is comparable to $S$. (Euomphalus) hoffmani. Although the species is intermediate in spire height between the two Rogers City species, the concave upper whorl face is more of a deviation from the "typical Straparollus" profile than either of those forms. In all forms of the second group there is considerable variation in the size of the pieces of implanted material. Nevertheless, the overall impression is that the first group implanted somewhat smaller pieces of foreign matter than the second group.

Straparollus (?Euomphalus) incrustatus from the Engelmann Formation of Utah bears some resemblance to the second group in rate of whorl expansion and general vagaries of position of scars. All available specimens show cicatrices. There is a flattening of the outer whorl faces so that the profile approaches angulation. The species differs from those of the second group in having a narrower um- 
bilicus and in lacking a circumbilical ridge. It is apparent that this species bears more resemblance to the second group than to the first. Still, it is an open question whether $S$. (?Euomphalus) incrustatus is distantly related to the second group or completely separate.

The other two species discussed in this paper are quite enigmatic in their relationships. Because Straparollus (Straparollus) sp. from the Marcellus Shale of New York is known only from a fragment, little can be said. It resembles the first group in slow rate of whorl expansion and general roundness of profile, but it does not have the uniformity of implantation that is so distinctive of that group. Straparollus (?Serpulospira) eboracensis from the Ludlowville of New York is hardly better known. Nevertheless, it is the most dissimilar form because of the rapid rate of whorl expansion. It bears little resemblance to any of the other forms except that it has a rounded whorl profile and implants foreign matter.

\section{CONCLUSIONS}

The implantation of foreign shell material by modern gastropods is a deliberate and purposeful act. The elaborate behavioral antics of Xenophora amply substantiate the conclusion that implantation is not accidental. Presumably this peculiar art is of considerable selective value to the animal that practices it.

The habit of implantation probably also had selective value for the Paleozoic carrier shells. The act of attaching shell material necessitated long periods of quiescence for the organism. In addition, once the foreign material was attached to the shell, it was necessary for the organism to lead a sedentary life, as active creeping about would destroy any effectiveness of camouflage by calling attention to the organism. Thus, the presence of incrusted material suggests that relative immobility was a characteristic of these Devonian euomphalids. Independent of this argument, Yochelson (1971) suggested that disjunctly coiled forms were adapted to a sedentary mode of life in which the shell lay flat on the substrate. In the specimen of $S$. (Serpulospira) centrifuga, both the disjunct coiling and the habit of attachment are seen. The assumption of limited movement and comparison with living Xenophora would support the argument that these forms had moved from a predominantly grazing habit to one of deposit or filter feeding.

The presence of large numbers of septa in at least some of the disjunctly coiled forms suggests that the soft parts were shortened and "worm-like" (Yochelson, 1971, p. 240-241), further reinforcing the notion of essentially a sessile mode of life.
The sessility of these Paleozoic euomphalids is thus inferred from three separate lines of evidence: (1) the disjunct coiling of forms like $S$. (Serpulospira), which would preclude anything short of "sitting" on top of soft sediments, (2) the presence of septa, which suggests a shortened, wormlike body, and (3) the camouflage effect of the implanted materials.

The cementing habit has evolved independently in several lines. It is known from the Ordovician and Devonian in the euomphalaceans, from the MiocenePliocene in the turritellids, and from the Cretaceous to Holocene in the xenophorids. The majority of the Devonian species examined are readily placed in two groups. They differ not only in the size of whorl expansion but also in the degree of implantation. It seems reasonable to conclude that the implanting habit evolved independently in at least two stocks during the Middle Devonian and that not all the incrusted forms are closely allied. If this inference is correct, the erratic stratigraphic occurrence of the forms during Middle and Late Devonian time is far more understandable.

North American species of carrier shells associated with Stringocephalus tend toward development of an outer angulation; accordingly, several species have been assigned to Straparollus (Euomphalus). It may be that this outer angulation is better expressed as a flattening of the outer whorl face with subsequent modification of the upper part of the whorl as a direct consequence. Flattening of the outer whorl face is readily interpreted as a more efficient method for allowing attachment to the shell of foreign fragments. We have followed convention in using this subgenus, but we suggest that in this instance the convention is misleading. Although we do not mean to imply that there is no validity to Euomphalus as it is normally used, we would suggest that unusually high-spired forms or those with a poorly developed upper angulation be considered carefully before being automatically assigned to that taxon.

Perhaps our views are best summarized by the comments of Ulrich and Scofield (1897, p. 1024) in a general discussion of the euomphalaceans. After noting the occurrence of fragments attached to Euomphalus eboracensis Hall, they stated that

Ecculiomphalus undulatus Hall had a similar habit, and its frequent occurrence in several European Devonian Euomphalidae has been observed by Deslongchamps, Koken and others, and quite recently has led Kayser to propose the new generic term Philoxene (Zeitschr. d. deutsch. geol. Gesellsch., Jahrg. 1889). This peculiar feature reminds one of the recent genus Phorus, but we agree fully with Hall and Koken in attaching very little significance to its presence in these otherwise clearly Euomphaloid shells. 


\section{SELECTED REFERENCES}

Archiac, E. J. A. d', and Verneuil, E. P. de, 1842, On the fossils of the older deposits in the Rhenish Provinces, preceded by a general survey of the fauna of the Palaeozoic rocks, and followed by a tabular list of the organic remains of the Devonian system in Europe: Geol. Soc. London Trans., v. 6, p. 303-410, pls. 25-37.

Bartsch, Paul, 1931, A new marine shell of the genus Xenophora from Florida: U.S. Natl. Mus. Proc., v. 80, art. 17, p. 1-2, pl. 1.

Clench, W. J., 1942, A remarkable development of pseudosculpture on a bivalve: Nautilus, v. 55 , no. 3 , p. $73-74$, pl. 6 .

Collins, R. L., 1934, Psammodulus, a new middle Miocene modulid from the isthmus of Tehuantepec, Mexico [abs.] : Nautilus, v. 47, no. 4, p. 127-130, pl. 13.

Cooper, G. A., and Phelan, Thomas, 1966, Stringocephalus in the Devonian of Indiana: Smithsonian Misc. Colln., v. 151, no. 1,20 p., pls. 1-5.

Cooper, G. A., and others, 1942, Correlation of the Devonian sedimentary formations of North America: Geol. Soc. America Bull., v. 53, no. 12, pt. 1, p. 1729-1794, pl. 1.

Cossmann, Maurice, 1915, Essais de paleoconchologie comparée, v. 10: Paris, privately printed, 292 p., 12 pls. [1916].

Ehlers, G. M., and Kesling, R. V., 1970, Devonian strata of Alpena and Presque Isle Counties, Michigan, in Guidebook for field trips - Geological Society of America North-Central Section, May 1970: [East Lansing, Mich.], Michigan Basin Geol. Soc., p. 1-30, pl. 38.

Ehlers, G. M., and Radabaugh, R. E., 1938, The Rogers City Limestone, a new Middle Devonian formation in Michigan: Michigan Acad. Sci., Arts and Letters Papers, v. 23, p. 441-446, 2 pls.

Erben, H. K., and Zagora, Karl, 1967, Devonian of Germany, in Oswald, D. H., ed., International Symposium on the Devonian System, Calgary, 1967: Calgary, Alberta Soc. Petroleum Geologists, v. 1, p. 53-68.

Fagerstrom, J. A., 1964, Fossil communities in paleoecology; their recognition and significance: Geol. Soc. America Bull., v. 75, no. 12, p. 1197-1216.

Fenton, C. L., and Fenton, M. A., 1924, The stratigraphy and fauna of the Hackberry stage of the Upper Devonian: Mich. Univ., Mus. Geology Contr., v. 1, 260 p., 45 pls.

Goldfuss, August, 1844, Petrefacta Germaniae. Dritter Theil: Dusseldorf, Arnz \& Comp., 128 p., Atlas of plates 166-200.

Hall, James, 1858, Report on the geological survey of the State of Iowa $* * *$ v. 1, pt. 2, Palaeontology: [Albany, N.Y.], p. 473-724, pls. 1-29.

1861 , Descriptions of new species of fossils from the Upper Helderberg, Hamilton, and Chemung groups; with observations upon previously described species: New York State Cabinet Nat. History Ann. Rept. 14, p. 99-109 [also apparently issued as a preprint with different pagination, as indicated by reference in Hall, 1879].

1862, Contributions to palaeontology; comprising descriptions of new species of fossils, from the Upper Helderberg, Hamilton, and Chemung groups: New York State Cabinet Nat. History Ann. Rept. 15, p. 29-80, pls. 1-11.

1876, Illustrations of Devonian fossils: Gasteropoda, Pteropoda, Cephalopoda, Crustacea and corals of the Upper Helderberg, Hamilton and Chemung groups: Al- bany, Weed, Parsons and Company, 136 pls. [This is a limited edition of 100 copies which reproduced essentially the plates and legends of Hall, 1879; there are some differences between this and the 1879 edition].

1879, Descriptions of the Gasteropoda, Pteropoda and Cephalopoda of the Upper Helderberg, Hamilton, Portage, and Chemung groups: New York Geol. Survey, Palaeontology, v. 5, pt. 2, 492 p., accompanying volume of 113 pls.

Hintze, F. F., Jr., 1913, A contribution to the geology of the Wasatch Mountains, Utah: New York Acad. Sci. Ann., v. 23 , p. $85-143$.

Johnson, J. G., 1970, Taghanic onlap and the end of North American Devonian provinciality: Geol. Soc. America Bull., v. 81, no. 7, p. 2077-2105.

Jux, Ulrich, 1964, Zur stratigraphischen Gliederung des Devonprofils von Bergisch Gladbach (Rheinisches Schiefergebirge) : Decheniana, v. 117, p. 159-174.

Kayser, F. H. E., 1889, Uber einige neue oder wenige gekannte Versteinerungen des rheinischen Devon: Deutsch. Geol. Gesell. Zeitschr., v. 41, p. 288-296, pls. 13, 14.

Knight, J. B., 1941, Paleozoic gastropod genotypes: Geol. Soc. America Spec. Paper 32, 510 p., 96 pls.

Knight, J. B., Batten, R. L., and Yochelson, E. L., 1960, [Descriptions of Paleozoic Gastropoda], in Moore, R. C., ed., Treatise on invertebrate paleontology, Part I, Mollusca 1: New York and Lawrence, Kans., Geol. Soc. America and Univ. Kansas Press, p. I169-I331.

Koken, Ernst, 1896, Die Leitfossilen: Leipzig, Chr. Herm. Tauchnitz, $848 \mathrm{p}$.

Koken, Ernst, and Perner, Jaroslav, 1925, Die Gastropoden des baltischen Untersilurs: Acad. Sci. Russie Mém., 8er Sér., Class. Phys.-Math., v. 37, no. 1, 322 p., 51 pls.

Koninck, L. G., de, 1843, Description des animaux fossiles, qui se trouvent dans le terrain carbonifère de Belgique: Liege, 650 p., 54 pls. [1842-1844].

Linsley, R. M., 1968, Gastropods of the Middle Devonian Anderdon Limestone: Bulls. Am. Paleontology, v. 54, no. 244 , p. $333-465$, pls. $25-39$.

McCabe, H. R., 1967, Field guide to Devonian outcrops of southwestern Manitoba: Manitoba Dept. Mines. Nat. Resources, $54 \mathrm{p}$.

McCammon, Helen, 1960, Fauna of the Manitoba Group in Manitoba: Manitoba Dept. Mines Nat. Resources Pub. 59-6, 109 p., 13 pls.

MacNeil, F. S., 1960, Tertiary and Quaternary Gastropoda of Okinawa: U.S. Geol. Survey Prof. Paper 339, 148 p. [1961].

Morton, J. E., 1949, Adaptations of Xenophora: New Zealand Sci. Rev., no. 7, p. 188-189.

1958, The adaptations and relations of the Xenophoridae (Mesogastropoda): Malacolog. Soc. London Proc., v. 33, pt. 3, p. 89-101, pl. 9.

Naef, Adolf, 1911, Studien zur Generellen Morphologie der Mollusken. Teil 1, Über Torsion und Asymmetrie der Gastropoden: Ergebnisse und Fortschr. Zoologie, v. 3, p. 73-164.

Perner, Jaroslav, 1907, in Barrande, Joachim, Système silurien du centre du la Bohême, v. 4, Gasteropodes, Tome 2 : Prague, 380 p., pls. 176-247.

Pilsbry, Henry, 1940, Land Mollusca of North America: Acad. Nat. Sci. Philadelphia Mon. 3, v. 1, pt. 2, p. 575-994.

Poole, F. G., and others, 1967, The southwestern United States, in Oswald, D. H., editor, International Sympo- 
sium on the Devonian System, Calgary, 1967: Calgary, Alberta Soc. Petroleum Geologists, v. 1, p. 879-912.

Ransome, F. L., 1916, Some Paleozoic sections in Arizona and their correlation: U.S. Geol. Survey Prof. Paper 98-K, p. 133-166.

Raup, D. M., 1966, Geometric analysis of shell coiling General problems: Jour. Paleontology, v. 40, no. 5, p. $1178-1190$.

Rutsch, R. F., 1943, Die Mollusken der Springvale-Schichten (Obermiocaen) von Trinidad (Britisch-West Indien) : Naturf. Gesell. Basel Verh., v. 54, 1942-43, p. 96-182, pls. 3-9.

Sandberger, Guido, and Sandberger, Fridolin, 1850-1856, Die Versteinerungen rheinischen Schichtensystems in Nassau: Wiesbaden, Kreidel \& Niedner, Verlagshandlung, 564 p., Atlas, 39 pls.

Savage, T. E., 1920, The Devonian formations of Illinois: Am. Jour. Sci., 4th ser., v. 49, p. 169-182.

Shank, Paul, 1969, The timorous carrier shell; close observations of Xenophora conchyliophora Born: New York Shell Club Notes, no. 151, p. 5-7.

Sohl, N. F., 1960, Archeogastropoda, Mesogastropoda, and stratigraphy of the Ripley, Owl Creek, and Prairie Bluff Formations: U.S. Geol. Survey Prof. Paper 331-A, $151 \mathrm{p} ., 18 \mathrm{pls}$.

Staatz, M. H., and Carr, W. F., 1964, Geology and mineral deposits of the Thomas and Dugway Ranges, Juab and Tooele Counties, Utah: U.S. Geol. Survey Prof. Paper 415,188 p., 9 pls.

Towe, K. M., 1967, Wall structure and cementation in Haplophragmoides canariensis: Cushman Found. Foraminiferal Research Contr., v. 18, pt. 4, p. 147-151, pls. 12, 13.

Tryon, G. W., 1886, Manual of conchology: Philadelphia, published by the author, v. 8, 461 p., 79 pls.

Ulrich, E. O., and Scofield, W. H., 1897, The Lower Silurian Gastropoda of Minnesota: Minnesota Geol. Survey Final Rept., v. 3, pt. 2, p. 813-1081, pls. 61-82.

Weisbord, N. E., 1962, Late Cenozoic gastropods from northern Venezuela: Bulls. Am. Paleontology, v. 42, no. 193, $672 \mathrm{p} ., 48 \mathrm{pls}$.
Weller, Stuart, 1903, The Paleozoic faunas: New Jersey Geol. Survey, Paleontology, v. 3, 462 p., 53 pls.

Wenz, Wilhelm, 1940, Gastropoda; Teil 4, Prosobranchia, in Schindewolf, O. H., Handbuch der Paläozoologie, v. 6 : Berlin, Gebruder Borntraeger, p. 721-960.

Whidborne, G. F., 1891, A monograph of the Devonian fauna of the south of England; v. I, Part III, The fauna of the limestones of Lummaton, Wolborough, Chircombe Bridge, and Chudleigh: Palaeontograph. Soc. Mon. 45, p. 155-250, pls. 16-24.

Whiteaves, J. F., 1891a, Descriptions of some new or previously unrecorded species of fossils from the Devonian rocks of Manitoba: Royal Soc. Canada Proc. Trans., v. 8 , sec. 4 , pt. 3, p. 93-110.

$1891 \mathrm{~b}$, The fossils of the Devonian rocks of the Mackenzie River basin: Canada Geol. Survey Contr. Canadian Paleontology, v. 1, pt. 3, no. 5, 197-253, pls. 27-32. 1892, The fossils of the Devonian rocks of the islands, shores, or immediate vicinity of Lakes Manitoba and Winnipegosis: Canada Geol. Survey Contr. Canadian Paleontology, v. 1, pt. 4, no. 6, p. 255-359, pls. 33-47.

Whitfield, R. P., and Hoovey, E. O., 1900, Catalogue of the type and figured specimens in the palaeontological collection of the geological department, American Museum of Natural History; Part 3, Beginning with the Oriskany Sandstone: Am. Mus. Nat. History Bull. 11, p. 190-356.

Woodring, W. P., 1958, Springvaleia, a late Miocene Xenophora-like turritellid from Trinidad: Bulls. Am. Paleontology, v. 38 , no. 169 , p. $163-174$, pl. 17.

Yochelson, E. L., 1963, The Middle Ordovician of the Oslo region Norway; 15, Monoplacophora and Gastropoda: Norsk Geol. Tidsskr, v. 43, no. 2, p. 133-213, pls. 1-8. 1971, A new Upper Devonian gastropod and its bearing on the problems of open coiling and septation: Smithsonian Contr. Paleobiology, no. 3, p. 231-241, pls. 1, 2.

Yochelson, E. L., and Linsley, R. M., 1972, Opercula of two gastropods from the Lilydale Limestone (Early Devonian) of Victoria, Australia: Nat. Mus. Victoria Mem., v. 33 , p. 1-14, pls. 1, 2. 



\section{INDEX}

[Italic page numbers indicate major references]

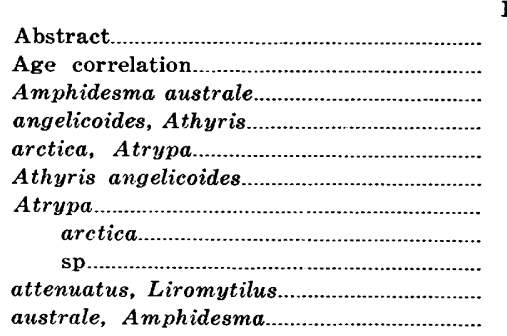

Page

1

strale, Amphidesmo

Bagworms.

borsoni, Tugurium (Trochotugurium)......

Brachiopod..

Buechelia tyrrellii...........................................

Caesticorbula...

calculiferum, Tugurium (Trochotugurium)

caperata, Xenophora.

caribeum, Tugurium (Trochotugurium)

Carinatina dysmorphostrota

Cassis.

.... 10, 14

centrifuga, Straparollus (Serpulospira) .... 8 $16,19,21 ; \mathrm{pl} .3$

Cephalopods.................................................. 18

conchyliophora, Xenophora......................... $s, 16$

corrugata, Xenophora.

Coscinasterias.............................................. 5

cottrelli, Straparollus (Straparollus) ....... 10

$11,14,17,18,19,20 ; \mathrm{pl}$.

Crabs.

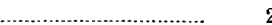

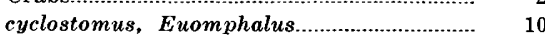

Straparollus (Straparollus) .................. 8

$10,11,14,17,19,20 ; \mathrm{pl} .3$

portlandensis, Straparollus.................. 10

Cyrtolites trentonensis .......................................

dysmorphostrota, Carinatina...................... 14

eboracensis, Euomphalus............................. 7, 21

Euomphalus (Phanerotinus) .................

Straparollus (Serpulospira) ............... 7 ,

$14,17,21 ; \mathrm{pl} .3$

Eccyliomphalus............................................ undulatus ........................................... 7,21

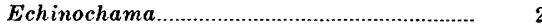

Endoptygma

Englemann Formation................................. 14

Euomphalidae............................................. 7, 21

Euomphalus .................................... 11, 12, 21

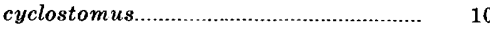
eboracensis .......................................... 7, 21 laevis................................................ 1, 19 serpens................................................... 6 serpula ............ 8 (Phanerotinus) eboracensis............... 7

(Euomphalus) hoffmani, Straparollus..... 9 $11,12,13,14,16,18,19,20 ;$ pl. 4 , incrustatus, Straparollus..................... 11 $13,14,17,20 ;$ pl. 6 Straparollus. winnipegosis, Straparollus.................. 13, $14,17,20$; pl. 6
Page

Foraminifera

Fossil localities. See Specimen localities.

Furnish, William, fossil-location descrip-

$$
\text { tion... }
$$

Page

Gastrocopta pentodon

Gravel Point Formation..

(Haliphoebus) solaris, Tugurium

Tugurium.

helvacea, Tugurium (Trochotugurium)

hoffmani, Straparollus (Euomphalus) .... $11,12,13,14,16,18,19,20 ;$ pl. 4,5

horni, Thysanophora............................... 2

Ikatere. .. 2 ; pl. 2

incrustata, Thysanophora.......................... 2 incrustatus, Straparollus (Euomphalus).. 11, $13,14,17,20 ;$ pl. 6

Straparollus (Straparollus) ..........11, 17, 19 indicum, Tugurium (Trochotugurium) ..... 3

Jurassiphorus ...............................................

konoi, Xenophora.

3

laevis, Euomphalus

Philoxene.

Straparollus (Straparollus) .................. 8, $g, 11,14,16,19 ;$ pl. 3

lamberti, Tugurium (Tugurium)... souverbie, Tugurium (Trochotugurium).

Lamelliphorus m)

Liromytilus attenuatus

Ludlowville Formation

Lytospira.

norvegica.

subuloidea

Maoricrepis....

Marcellus Shale

modulids

mortoni, Straparollus (Straparolhs)

14, 16,17, 18, $20 ;$ pl. 6

multispina, Straparollus (Philoxene)........ 9

Nautilus.............................................. 18 neozelanica, Xenophora................. $3,4,17$; pl. 2 norvegica, Lytospira

Omphalocirrus sp

Omphalotrochus

ophirensis, Straparollus

Orthis..

Oyster drill

pallidula, Xenophora

pentodon, Gastrocopta

Phanerotinus

philosophus, Philoxen

Philoxene. Philoxe

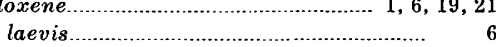

philosophus...

(Philoxene) multispina, Straparollus

Phorus

portlandensis, Straparollus cyclostomus.
Pleurotomaria.
Psammodulus.

Page

Pupillidae............................................................ 2

quadrangularis, Samarangia $\ldots \ldots \ldots \ldots \ldots \ldots \ldots \ldots . . . . . . . .2$

Rogers City Limestone

11,14

Sagdidae....

Samarangia quadrangularis

sapiens, Stringocephalus.

Scaliola..

Scofield, W. $\mathrm{H}$, and Ulrich, $\mathrm{E}$. O., validity of taxonomy

Selected references...

serpens, Euomphalus.

serpula, Euomphalus.

Straparollus (Serpulospira) .................

Serpularia.

Serpulorbis sp

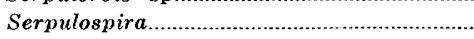

(Serpulospira), Straparollus........................

centrifuga, Straparollus..............

$16,19,21 ;$ pl. 3

eboracensis, Straparollus.................. 7,

serpula, Straparollus........................... 8

Shank, Paul, observations on cementation 4

Ship worm................................................ 19

Skaneateles Formation..................................... 14

solaris, Tugurium (Haliphoebus) .................

Solarium........................................................ 8

souverbie, Tugurium (Trochotugurium) lamberti

Specimen localities, Bikini.................................

Canada ............................. 13, 14, 20 ; pl. 6

Florida ................................ 4

Germany, Bohemia.................................... 6 Bucheler bed...................................... 15 evolutionary groups..................... 19

Paffrath beds.............. 8, 9, 14, $19 ; \mathrm{pl} .3$

Hawaii

Indian Ocean ................................................ 2

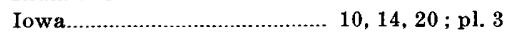

Japan ............................................ 2

Mexico

Michigan ............... 1, 9,12, 14, $20 ; \mathrm{pl.} \mathrm{4,5,6}$

Nevada

New York ....................... 2, 7, 9, 14 ; pl. 3, 5 evolutionary groups..................... 21

New Zealand..................................... 2, 4 ; pl. 2

North America, evolutionary groups 19

Pacific Ocean....................................... 2, 6

Philippines.................................................... pl. 2

Scandinavia............................................ 6

Tennessee …........................................... 17

Trinidad .................................................. 6

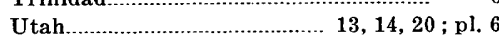

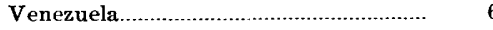

Wednesday Island...................................

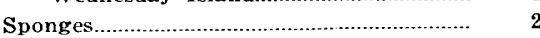

Springvaleia ..............................................

Starfish.......................................................... 5

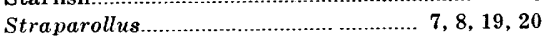

cyclostomus portlandensis.................... 10

ophirensis............................................ 14

(Euomphalus) ........................................ 21 hoffmani ................................... 9 $11,12,13,14,16,18,19,20 ;$ pl. 4,5 


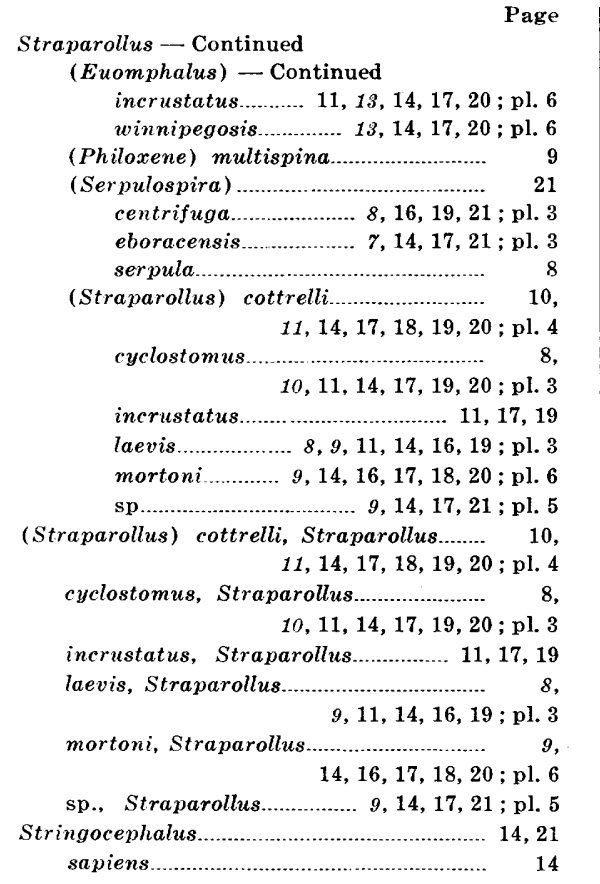

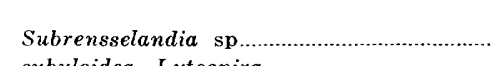
subuloidea, Lytospira

Teredo.

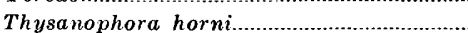
incrustata.

Traverse Group.

trentonensis, Cyrtolites. (Trochotugurium) borsoni, Tugurium..... calculiferum, Tugurium.

caribeum, Tugurium

helvacea, Tugurium

indicum, Tugurium.

lamberti souvertie, Tugurium.............

longleyi, Tugurium

Tunicates

Tugurium

(Haliphoebus) ...................................... 3,6

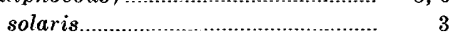

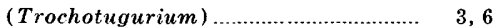

borsoni.

calculiferum ......................................

caribeum...

helvacea.

indicum.

lamberti souverbie

longleyi.

(Tugurium) exutum.

Page
14
6

19
2
2
14
7
3
3
3
3
3
3
3
3,6
2
2,6
3,6
3
3,6
3
3
3
3
3
3
3
3,6
3

Page

Tugurium -- Continued

(Tugurium) - Continued lamberti.

(Tugurium) exutum, Tugurium lamberti, Tugurium.............................. 15

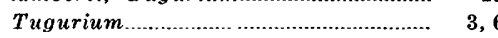

turritellids............................................... 6, 21

tyrrellii, Buechelia ......................................

Ulrich, E. O., and Scofield, W. H., validity$$
\text { of taxonomy. }
$$

undulatus, Eccyliom phalus............................. 7, 21

Vermetid..

winnipegosis, Straparollus (Euomphalus) 13 $14,17,20$; pl. 6

Worm burrows and tubes.

$1,3,18,21$

Xenophora. caperata

compared to Lytospira

conchyliophora ...................................... 3,16

corrugata...................................................

enica... $3,4,17 ; \mathrm{pl}, 2$

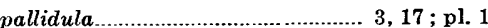

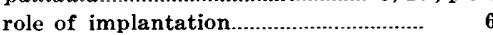

selection of material

size of implanted material.

Xenophoridae 


\section{PLATES $1-6$}

Contact photographs of the plates in this report are available, at cost, from the U.S. Geological Survey Library, Federal Center, Denver, Colorado 80225. 


\title{
PLATE 1
}

Figures 1-5. Xenophora pallidula (Reeve).

\author{
[All figures $\times 1]$
}

1, 5. Oblique apical and side adapertural views of USNM 238277, U.S. Bur. Fisheries (USBF) station 5408, off Point Pinulacau, Cebu, Philippines, 159 fathoms, in green mud. The material implanted on the earliest whorls of this specimen has been broken off, leaving attachment scars, whereas material implanted on adult whorls is still attached. The earliest implanted materials are rounded clam shells, which were attached by their outer surface. Then two small corals were attached and, on the final whorl and a half, six different species of high-spired gastropod shells. The specimen was subsequently incrusted with serpulid worm tubes and solitary corals on the attached snails at lower center and right.

2. Apical view of USNM 238192, USBF station 5392, off Desbacado Island, Philippines, 135 fathoms, in green mud. The early whorls of this specimen are obscured by incrusting organisms, such as serpulid worm tubes and a large barnacle (center right). Most of the implanted material on the early whorls is small corals. On the adult whorls it consists of larger solitary corals and elongated gastropod shells.

3. Oblique apical view of USNM 243411, USBF station 5278, north of Ambil Island, Luzon, Philippines, 102 fathoms in fine sandy mud. The earliest implanted material on this specimen was small pebbles, followed by two small corals and elongated gastropod shells. Note the dark-gray shell below and the very dark gray pebble above in the midst of lighter colored pink to gray shells.

4. Oblique apical view of USNM 243374, USBF station 5265, Butangas Bay, Luzon, Philippines, 135 fathoms, in sandy mud. The specimen began by implanting pebbles; this was followed in the adult whorls by implantation of a mixture of pebbles, clam shells, and high-spired snails. 


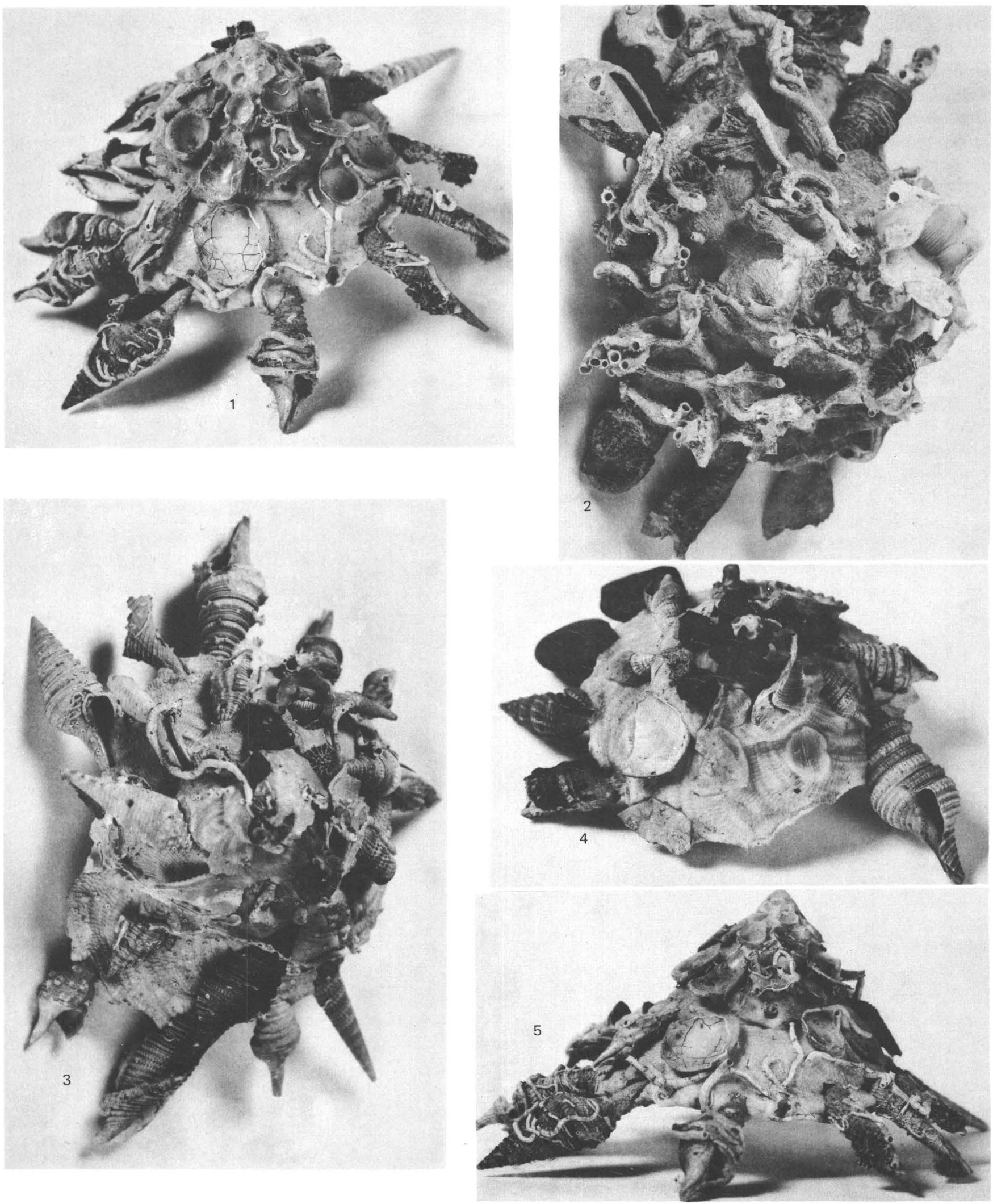

XENOPHORA PALLIDULA REEVE 


\section{PLATE 2}

[All figures $\times 1 \frac{1}{1 / 2}$ ]

Figures 1-5. Xenophora neozelanica Suter. All specimens captured by prawn trawl with tickler, 5 miles east of Takatau Point, north of Auckland, New Zealand, in 27 to 30 fathoms of water. Station 314 (22-9-71) of Ikatere, New Zealand Marine Department. Lat $36^{\circ} 22^{\prime} 30^{\prime \prime}$ S., long $174^{\circ} 59^{\prime 2} 24^{\prime \prime} \mathrm{E}$. Substrate consists of dark-gray mud rich in organic matter, with abundant shell cover.

1. Apertural view of specimen in normal feeding position with foot held off substrate. Proboscis reaching out to scrape algae off shell. Note mucus secreted by foot and the operculum in a vertical position.

2. Basal view of animal, showing inverted position of soft parts typical of search behavior for shell material. The proboseis and tentacles are against the substrate while the broadly expanded propodium searches for foreign matter to be implanted onto its shell. A large slipper shell (Maoricrepis) is on the base at the right center of the figure.

3. Oblique anterior view of male in typical feeding behavior. Tentacles and proboscis search for food with foot suspended off the substrate. The basal part of penis is seen emerging from the right side of the snail's muscular column.

4. Side view of animal during search behavior. The soft parts are inverted beneath tentlike canopy of the shell; the proboscis lifts the shell by pushing against the substrate while the propodium searches for material suitable for implantation.

5. Basal view showing animal engaged in cleaning activity. The broad propodium is directed down to the right, the metapodium is not in contact with the substrate and therefore is relatively narrow. The proboscis is curved around to clean the underside of the operculum. The mantle extends almost to the outer lip, and the gill is just to the left of the propodium. The black dots are feces behind the metapodium. 
GEOLOGICAL SURVEY
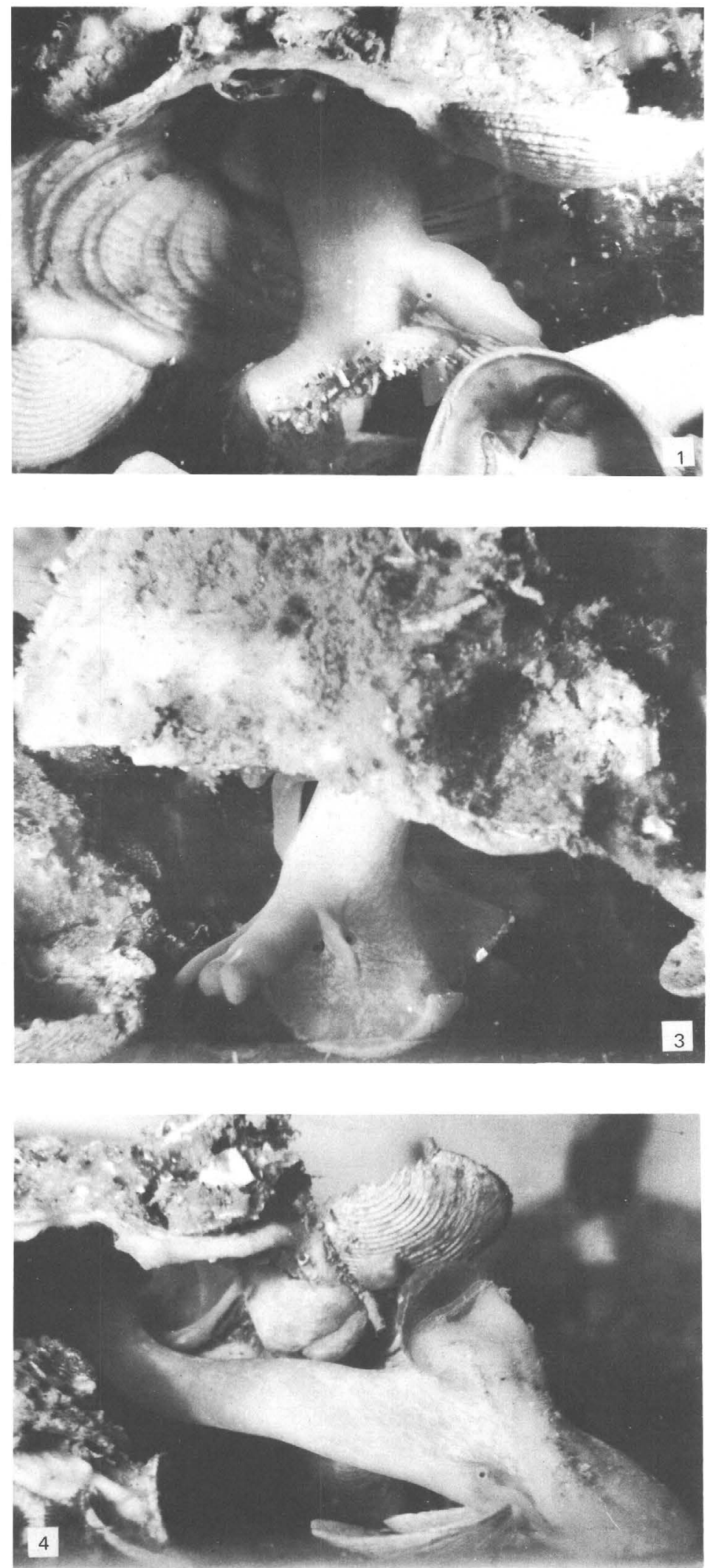

PROFESSIONAL PAPER 824 PLATE 2
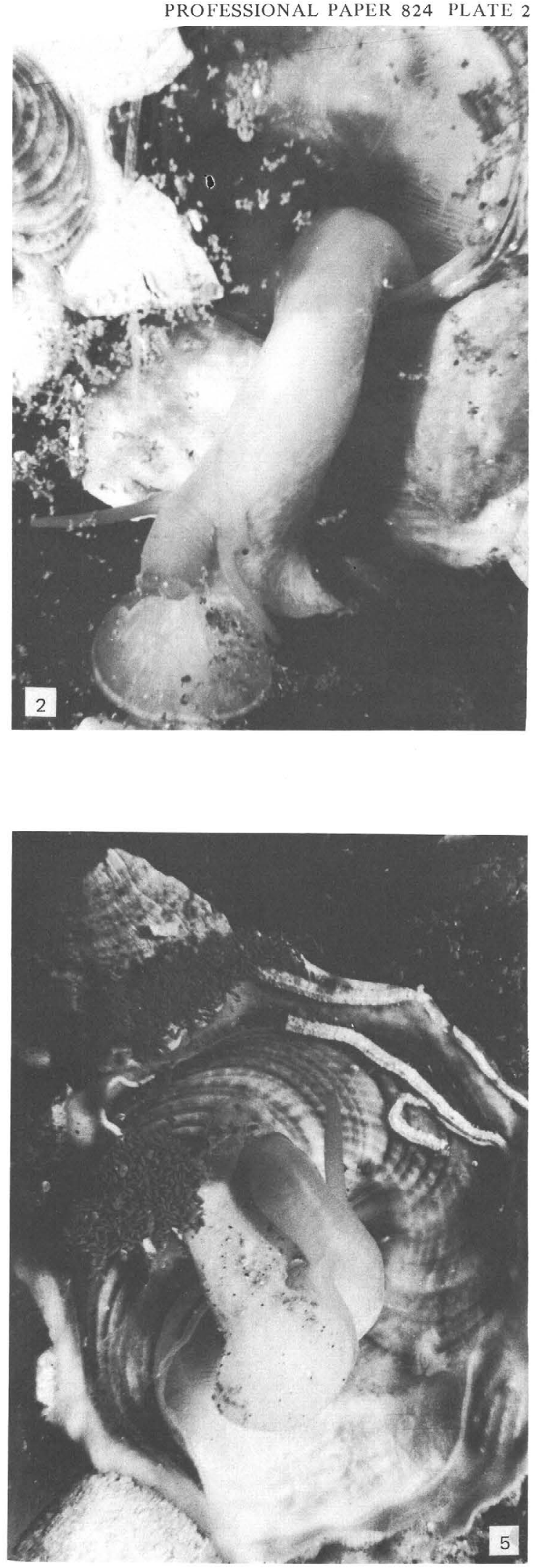


\section{PLATE 3}

Figures 1-3. Straparollus (Straparollus) laevis (Archiac and Verneuil) (p. 8).

Apical, oblique basal, and side views $(\times 2)$ of hypotype, USNM 58498, Paffrath beds, Germany. Note the uniform spacing of the scars at the periphery.

4, 5. S. (Straparollus) ?laevis (Archiac and Verneuil) (p. 9).

Side and basal views $(\times 2)$ of hypotype, USNM 63255, Paffrath beds, Germany. Note even spacing of attachment scars and their position low on the outer whorl face.

6, 7, 12-18. S. (Straparollus) cyclostomus (Hall) (p. 10).

From Cedar Valley Limestone $\left(\times 1 \frac{1}{2}\right)$.

6. Adapertural view of hypotype, USNM 183657, from quarry on Sweetland Creek, Muscatine County, Iowa. This is one of the largest specimens in this collection, but there are no signs of any attachment.

7. Side view of broken hypotype, USNM 183656, from 5 miles above Muscatine, Iowa. This rather large specimen has only a single attachment scar, well back from the aperture.

12-15. Basal, oblique apical, apical and apertural views of hypotype, USNM 183655, from 5 miles above Muscatine, Iowa. This large rugose specimen has many irregularly spaced attachment scars.

16-18. Apertural, apical, and basal views of hypotype, USNM 183658, from quarry on Sweetland Creek, Muscatine County, Iowa. This small well-preserved specimen shows no cicatrices.

8-11. S. (Serpulospira) centrifuga (F. A. Roemer) (p. 8).

Apical, oblique basal, apertural, and oblique apical views $(\times 2)$ of hypotype, USNM 183651, collected from the Paffrath beds near Bergische Gladbach near Cologne, Germany. This specimen has the disjunct coiling so typical of the subgenus, but also has attachment scars, evenly distributed at the periphery, much as in $S$. (Straparollus) laevis; compare with figures $1-3$.

19-21. S. (?Serpulospira) eboracensis (Hall) (p. 7).

Apical, oblique apical, and side views $(\times 2)$ of lectotype, AMNH $\frac{4890}{1}$, from the Ludlowville Formation near York, N.Y. Although this specimen is so poorly preserved that its subgeneric designation is questionable, it does have the encrusting habit, with the impressions of the fragments still intact. 
GEOLOGICAL SURVEY

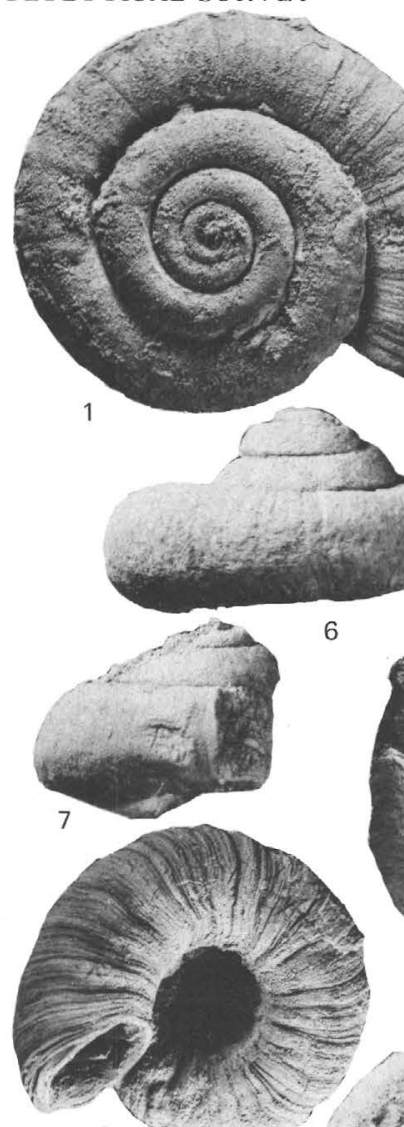

12

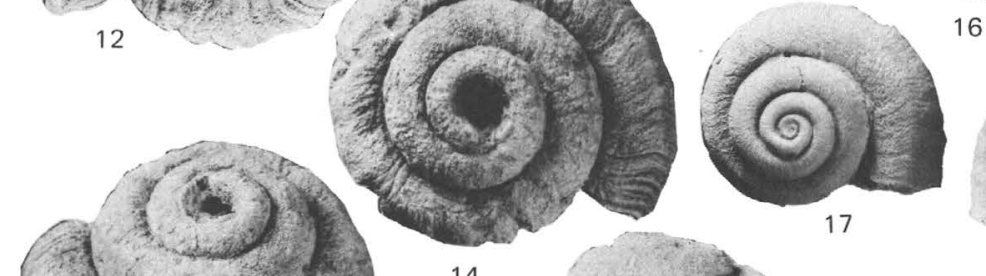

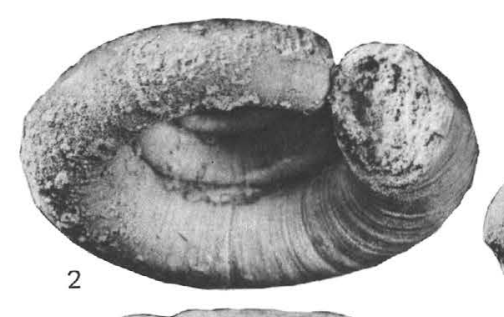

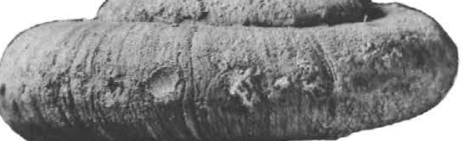

mind 3

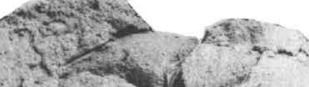
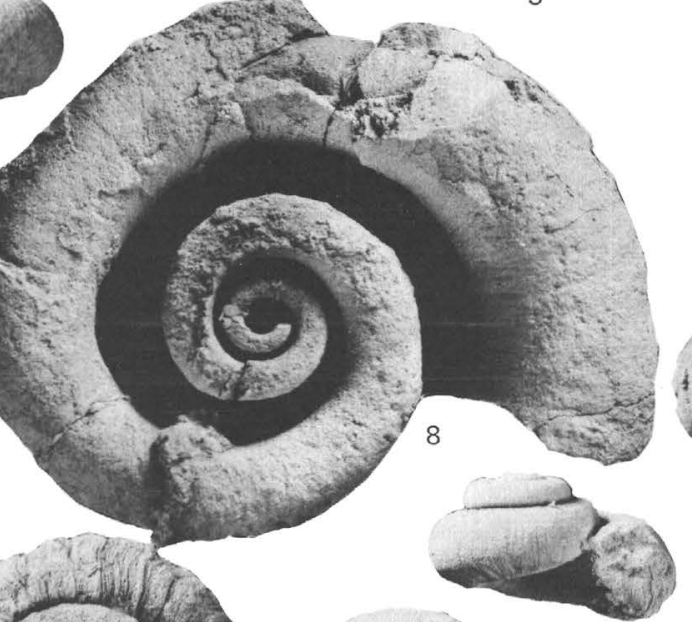

16

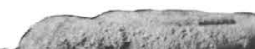

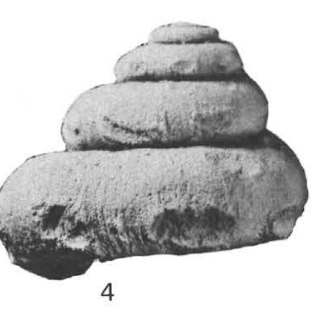
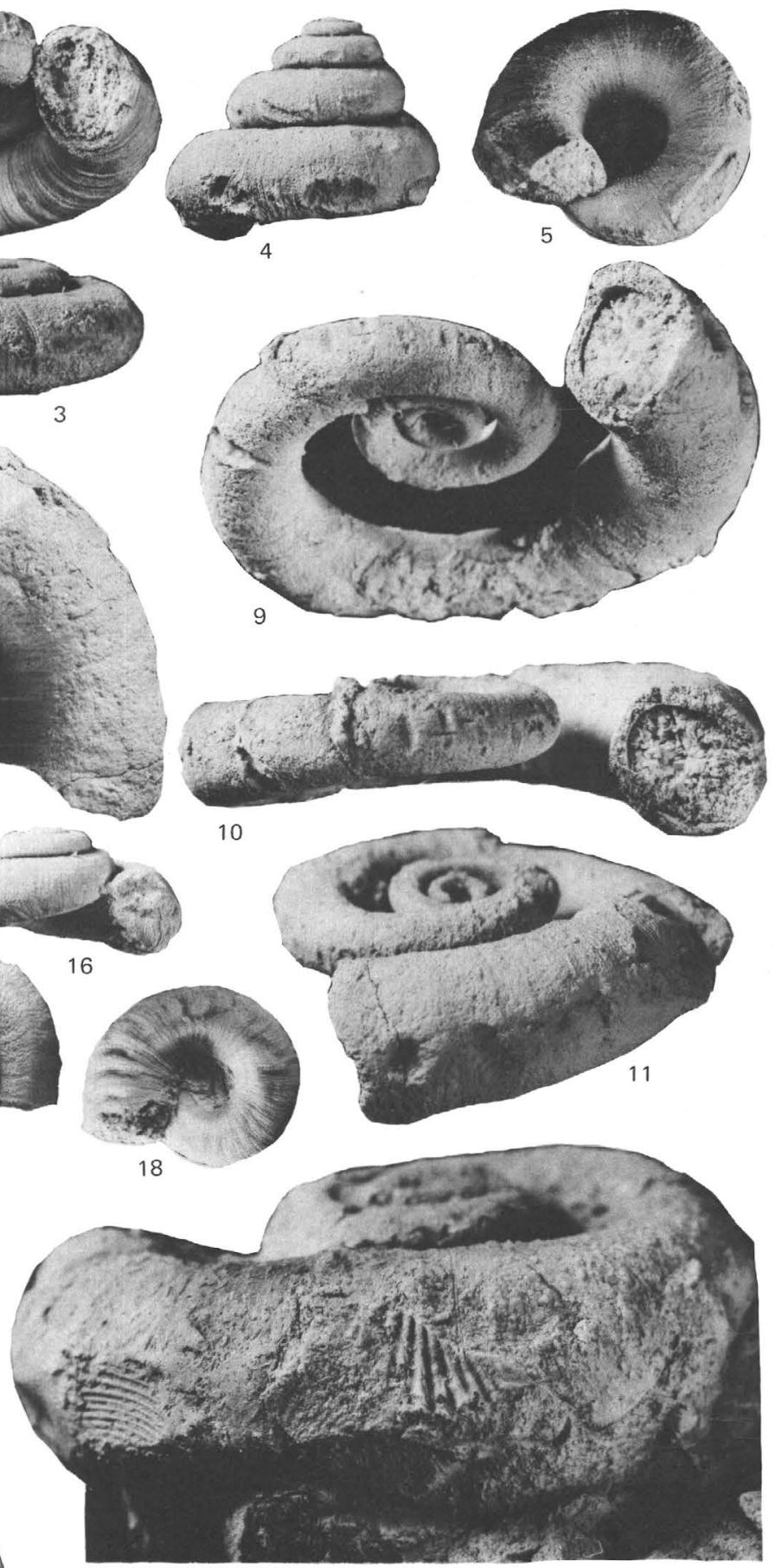

20

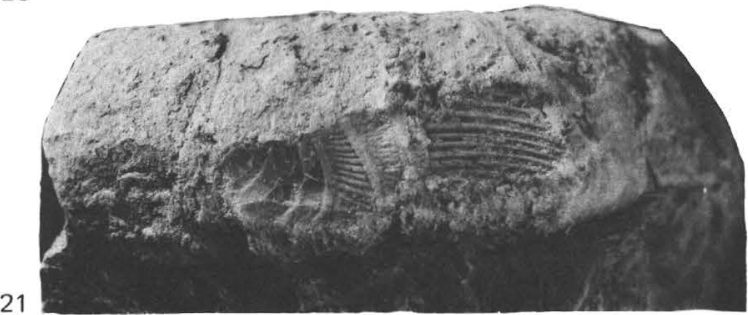

STRAPAROLLUS (STRAPAROLLUS) AND S. (SERPULOSPIRA) 


\section{PLATE 4}

Figures 1-12. Straparollus (Straparollus) cottrelli n. sp. (p. 11).

All specimens from unit 1 of the Rogers City Limestone of northeast Michigan, except specimen shown in figure 11, which is from unit 2.

1, 4. Apical and basal views $(\times 2)$ of holotype, USNM 183659. Note the essentially rounded whorl profile, circumbilical ridge, and the two immature specimens of $S$. (S.) cottrelli that have been implanted.

2 , 5. Basal and apical views $(\times 2)$ of paratype, UMMP 22375 . This is a crushed specimen which still shows the essential features of the species. Note the implanted bellerophontid and immature specimen of $S$. (S.) cottrelli.

3. Oblique apical view $(\times 2)$ of paratype, USNM 183660.

6. Oblique apical view $(\times 2)$ of paratype, USNM 183679. Although this is a large specimen, there is only one discernible cicatrix on it.

7-10. Basal, apical, apertural, and adapertural side views $(\times 1)$ of paratype, USNM 183661. This slightly crushed specimen has abundant attachment scars located consistently at the periphery.

11. Oblique apical view $(\times 2)$ of paratype, USNM 183662. This individual accreted a variety of shells to its own.

12. Apical view $(\times 1)$ of paratype, USNM 183663, which shows that material was implanted in the second preserved volution.

13. S. (S.) cf. S. (S.) cottrelli. Basal view $(\times 1)$ of figured specimen, USNM 183664. This specimen is from unit 3 of the Rogers City Limestone and is thought to be somewhat transitional in form between $S$. (S.) cottrelli and $S$. (Euomphalus) hoffmani.

14. Latex cast $(\times 1)$ UMMP 22424, of a block from the basal unit of the Rogers City Limestone. The well-sorted nature of these deposits suggests sorting by current action, probably by waves in a restricted lagoonal or supratidal habitat. More than 50 percent of the specimens in this block are $S$. (S.) cottrelli. 

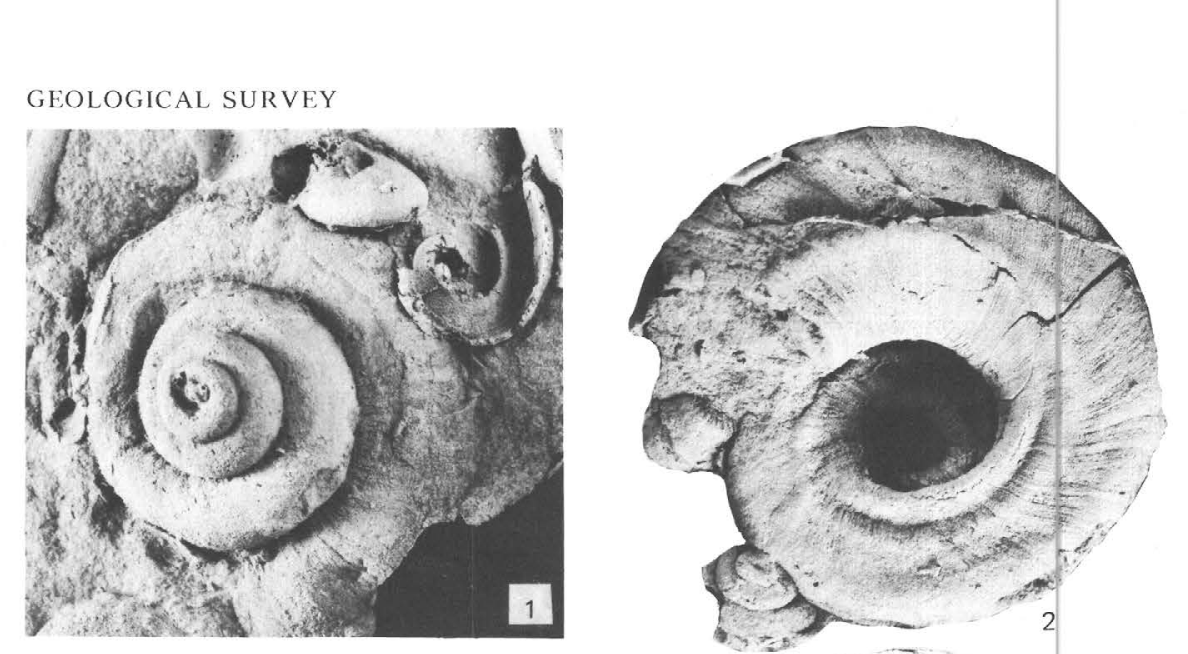

PROFESSIONAL PAPER 824 PLATE 4
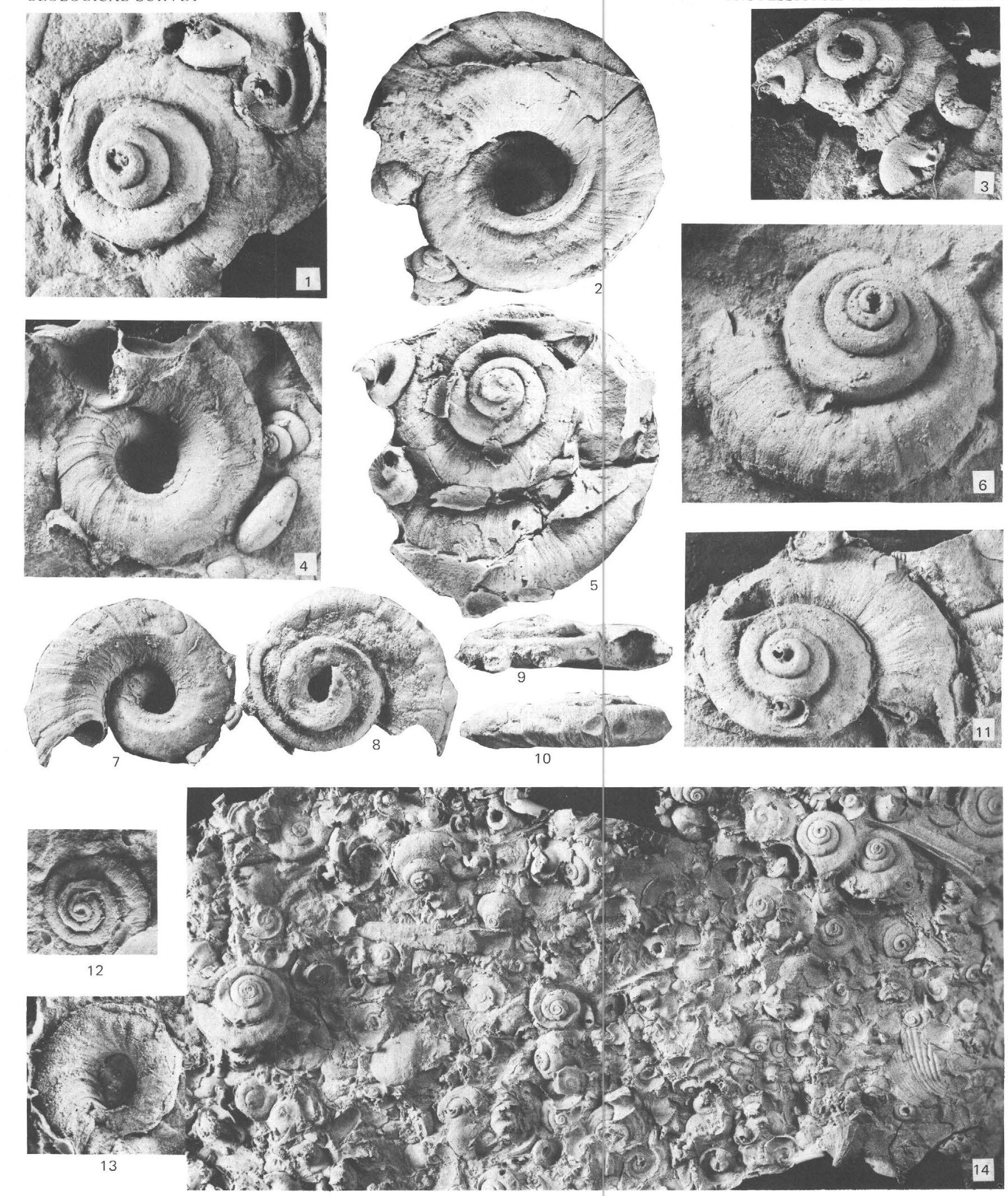

STRAPAROLLUS (STRAPAROLLUS) 


\section{PLATE 5}

FIGURES 1-19. Straparollus (Euomphalus) hoffmani n. sp. (p. 12).

All specimens collected from the upper three units of the Rogers City Limestone in northeastern Michigan.

1. Oblique apertural view $(\times 1)$ of paratype, USNM 183666, a small exceptionally well preserved specimen which shows the circumbilical ridge and has few attachment scars.

$2,3,6$. Oblique basal, oblique apical, and side views $\left(\times 1 \frac{11 / 2}{)}\right.$ of paratype, UMMP 22374.

4,8 , 12. Side, basal, and apical views $(\times 2)$ of paratype, UMMP 22370 . This is an unusual immature specimen in that it has not yet developed the angulation between the upper and outer whorl faces. It bears just one very large cicatrix.

5. Side view $(\times 1)$ of paratype, USNM 183667.

7, 11. Oblique apical and apical views $(\times 1)$ of holotype, UMMP 22369. This large specimen shows the angulation between the flattened upper and outer whorl faces and abundant attachment scars.

9. Apertural view $(\times 1)$ of paratype, USNM 102938, an unusually high-spired individual.

10, 13, 14. Apertural, adapertural, and oblique basal views $(\times 1)$ of paratype, UMMP 22372. Although implantation scars are common over the early whorls, the last half volution is free of scars.

15, 18, 19. Apertural, side, and basal views of paratype $\left(\times 1 \frac{1}{2}\right)$, UMMP 57888. This is an unusually high spired form and one of the largest specimens; cicatrices almost abut each other.

16. Apertural view $\left(\times 1 \frac{1}{2}\right)$ of paratype, USNM 183665, a large moderately high spired form.

17. Side view $(\times 2)$ of paratype, UMMP 57889. This immature specimen, even at a young stage, has the flattened outer whorl face and the angulation separating the upper and outer faces.

20. Straparollus (Straparollus) sp. (p. 9).

Oblique apical view $(\times 2)$ of figured specimen, USNM 183652, from the "Cardiff Shale

Member" of the Marcellus Shale, Hamilton Group, 3 miles south of Peterboro, N.Y. 

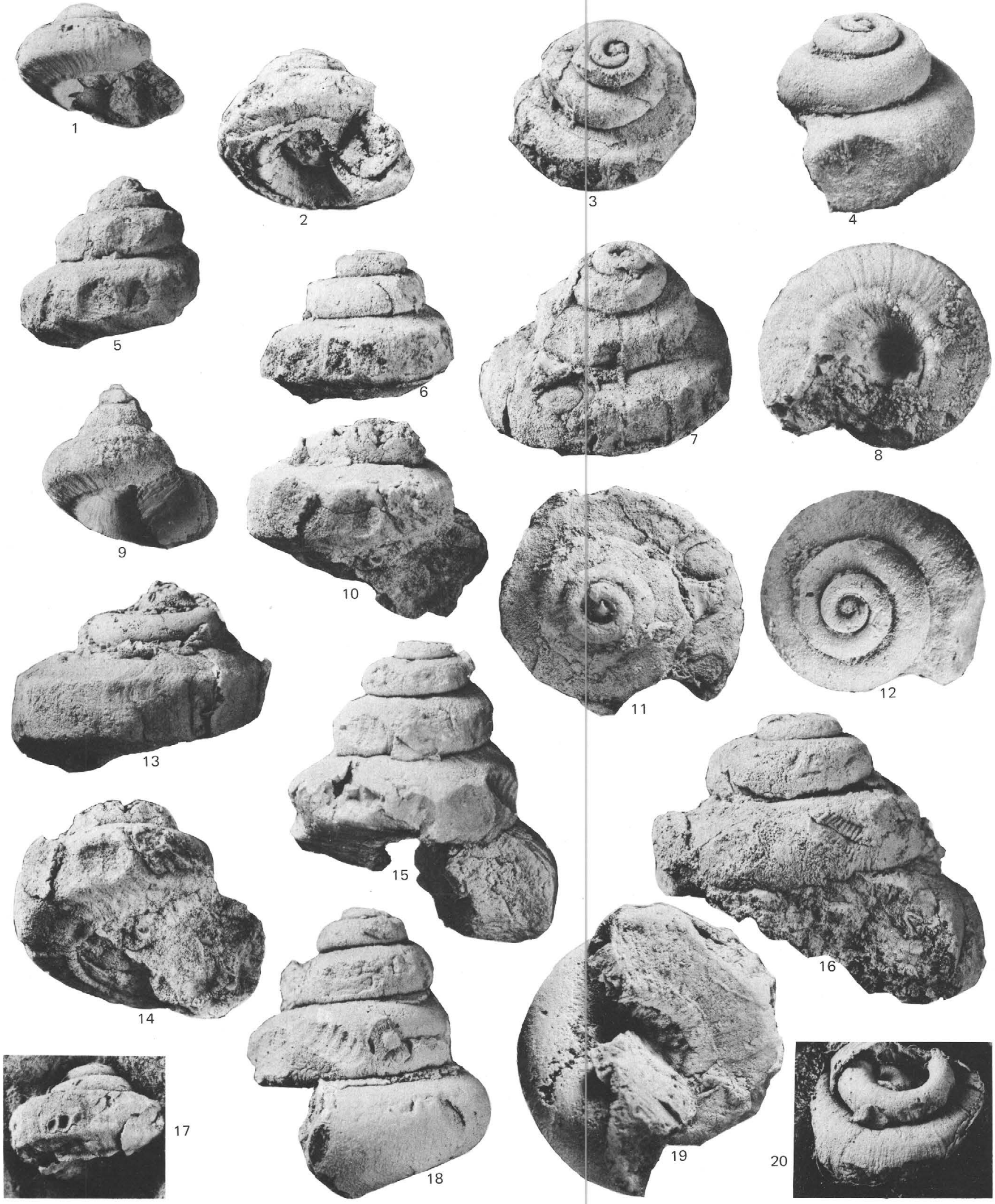

STRAPAROLLUS (EUOMPHALUS) AND S. (STRAPAROLLUS) 


\section{PLATE 6}

Figures 1-4. Straparollus (Straparollus) mortoni n. sp. (p. 9).

From the lower part of the Gravel Point Formation at the Marvin quarry, SW 1/4 NW 1/4 sec. 7, T. 34 N., R. 1 W., Cheboygan County, Mich.

1, 2. Apical and oblique apical views $(\times 2)$ of latex cast of holotype, USNM 183653, showing numerous cicatrices evenly distributed around the periphery.

3 , 4. Slightly oblique side and apical views $(\times 2)$ of latex cast of paratype, USNM 183654, higher spired than the holotype.

5-18, 20. S. (?Euomphalus) incrustatus n. sp. (p. 13).

From the Engelmann Formation, at USGS loc. 5829-SD, Thomas Range, Utah.

5-7. Apertural, apical, and basal views $(\times 3)$ of paratype, USNM 183677.

8. Side view $(\times 3)$ of broken paratype, USNM 183676, showing whorl cross section and absence of circumbilical ridge.

9. Basal view $(\times 1)$ of paratype, USNM 183675.

10. Adapertural side view $(\times 2)$ of paratype, USNM 183674, with several scars of attachment on body whorl.

11. Side view $(\times 3)$ of fragmentary paratype, USNM 183673, showing scars penetrating the silicified shell.

12, 18. Adapertural and cross-sectional side views $(\times 3)$ of paratype, USNM 183670. Note fragment attached to penultimate and body whorls and additional scars on body whorl.

13, 14, 16. Side, basal, and apical views $(\times 3)$ of paratype, USNM 183671, which has attached a juvenile specimen.

15. Oblique side view $(\times 3)$ of fragmentary paratype, USNM 183672, with two large scars on the body whorl.

17, 20. Adapertural and apical views $(\times 1)$ of holotype, USNM 183669. In spite of crushing of the body whorl, growth lines are clear; implantation scars are prominent on the penultimate whorl.

19, 21. S. (Euomphalus) winnipegosis n. sp. (p. 13).

From the Winnipegosis Formation about 1/4 mile west of The Narrows of Lake Manitoba. Side and oblique apical views $(\times 2)$ of latex cast of holotype, USNM 183668. This shows concave upper whorl surface and flattened outer whorl face with angulation between; attachment scars are abundant on outer whorl face. 

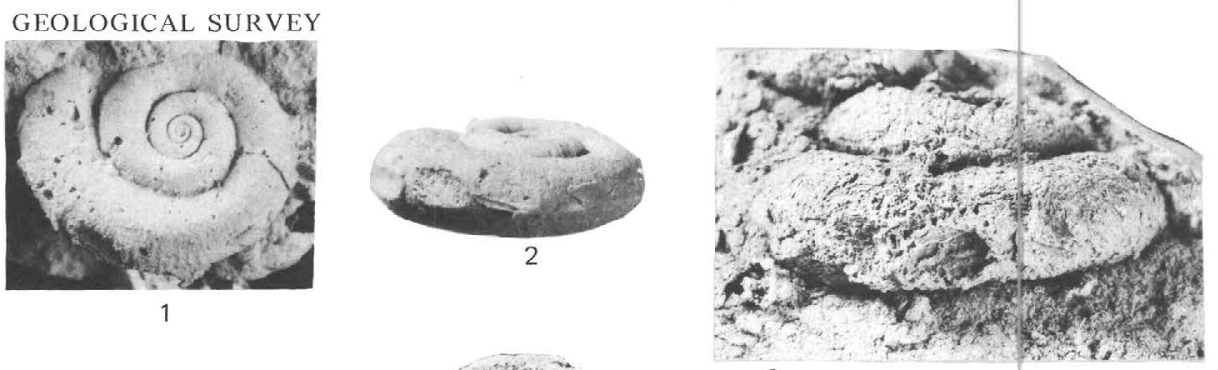

PROFESSIONAL PAPER 824 PLATE 6
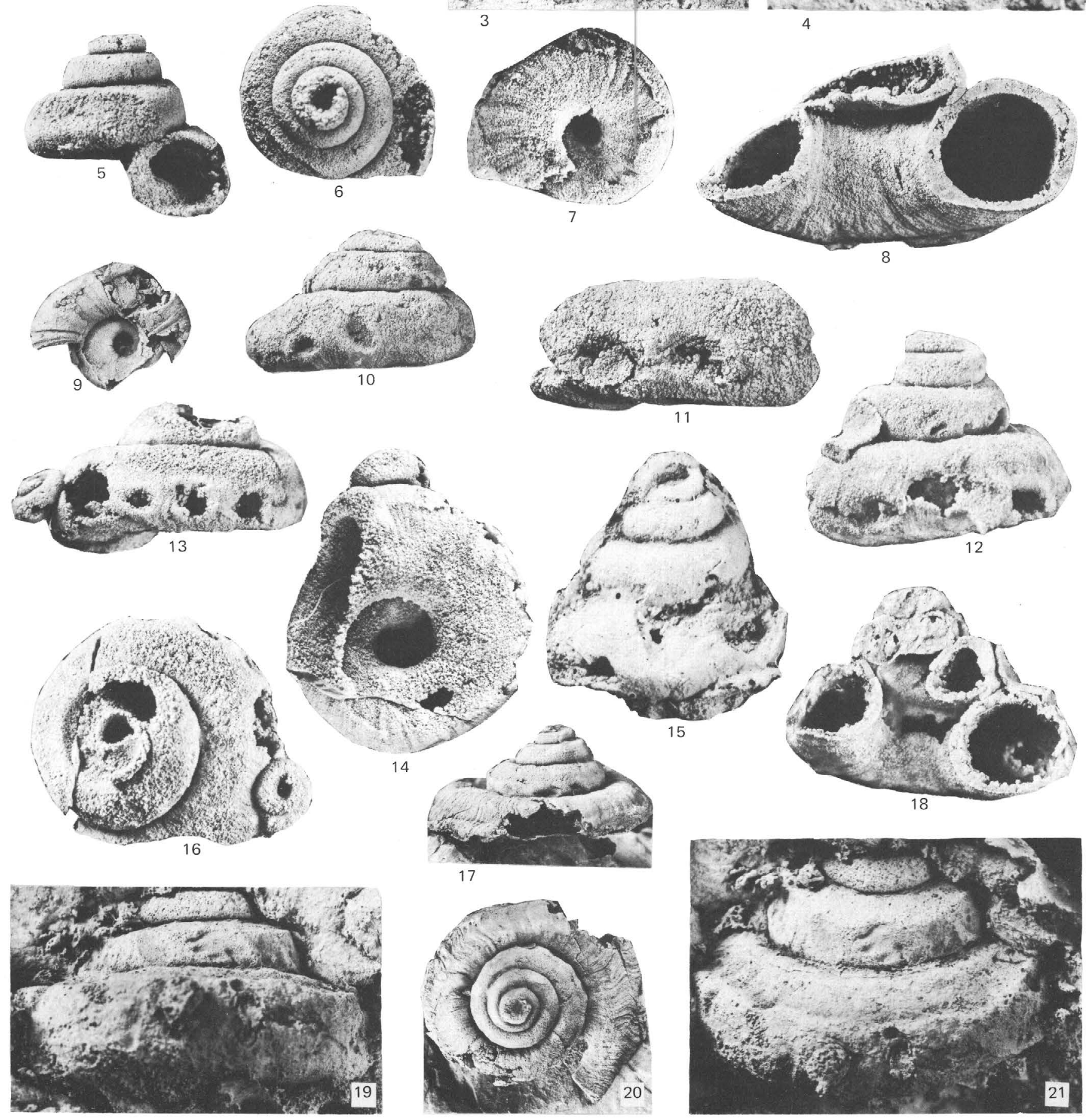

STRAPAROLLUS (EUOMPHALUS) AND S. (STRAPAROLLUS) 
